\title{
Millennial-scale sea surface temperature variability in the western tropical North Atlantic from planktonic foraminiferal census counts
}

\author{
Matthias Hüls and Rainer Zahn ${ }^{1}$ \\ GEOMAR Research Center for Marine Geosciences, Kiel, Germany
}

\begin{abstract}
Planktonic foraminiferal census counts are used to construct high-resolution sea surface temperature (SST) and subsurface (thermocline) temperature records at a core site in the Tobago Basin, Lesser Antilles. The record is used to document climatic variability at this tropical site in comparison to middle- and high-latitude sites and to test current concepts of cross-equatorial heat transports as a major player in interhemispheric climate variability. Temperatures are estimated using transfer function and modern analog techniques. Glacial - maximum cooling of $2.5^{\circ}-3^{\circ} \mathrm{C}$ is indicated; maximum cooling by $4^{\circ} \mathrm{C}$ is inferred for isotope stage 3 . The SST record displays millennial-scale variability with temperature jumps of up to $3^{\circ} \mathrm{C}$ and closely tracks the structure of ice-core Dansgaard/Oeschger cycles. SST variations in part of the record run opposite to the SST evolution at high northern latitude sites, pointing to thermohaline circulation and marine heat transport as an important factor driving SST in the tropical and high-latitude Atlantic, both on orbital and suborbital timescales.
\end{abstract}

\section{Introduction}

Millennial - scale variability is observed in paleoceanographic records throughout the world ocean. The records come from ocean regimes that are sensitive to changes in ocean and atmosphere circulation such as wind-driven equatorial and coastal upwelling [Wang et al., 1995; McIntyre and Molfino, 1996; Little et al., 1997; Martinez et al., 1999], mid-depth and marginal basin oxygen minimum zones [Haug et al., 1998; Schulz et al., 1998; Kennett and Ingram, 1995; Behl and Kennett, 1996] and from hydrologic fronts between deep water masses [Keigwin and Jones, 1994; Curry and Oppo, 1997; Lund and Mix, 1998; Keigwin and Boyle, 1999]. Some of the records closely mimic paleoclimatic proxy records from Greenland ice cores, which indicate rapid climatic change in the North Atlantic region [e.g., Dansgaard et al., 1993; Grootes et al., 1993; Taylor et al., 1993; Grootes and Stuiver, 1997; Mayewski et al., 1994]. Much of the millennial-scale variability has been linked to rapid changes of the ocean's thermohaline circulation in conjunction with North Atlantic thermohaline instabilities and far-field responses of the deep ocean. This contention receives some support from paleoceanographic records from the middle- and high-

1 Now at Cardiff University, Cardiff, Wales, UK.

Copyright 2000 by the American Geophysical Union.

Paper number 1999PA000462.

0883-8305/00/1999PA000462\$12.00. latitude North Atlantic, which display rapid fluctuations of planktonic foraminiferal assemblages, planktonic and benthic isotopes, and lithic particles, which all indicate abrupt changes of the North Atlantic's circulation and climate at the same pace seen in the Greenland ice core climatic records [Bond et al., 1993; Sarnthein et al., 1994; Bond and Lotti, 1995; Maslin et al., 1995; Sarnthein et al., 1995; Jung, 1996; Lebreiro et al., 1996; Rasmussen et al., 1996; Zahn et al., 1997; Waelbroeck et al., 1998; Völker et al., 1998; Keigwin and Boyle, 1999].

Interhemispheric heat transfer through the ocean's thermohaline circulation and atmospheric teleconnections have been referred to as drivers for climatic coupling between both hemispheres [Crowley, 1992; Stocker, 1992; Charles et al., 1996; Blunier et al., 1998]. Numerical models link an early warming of the Southern Hemisphere to a slowdown of thermohaline circulation, which causes cross-equatorial heat transport to be reduced, the North Atlantic to cool, and the tropical and high-latitude South Atlantic to warm in response to reduced heat export [e.g., Manabe and Stouffer, 1997].

Here we present a high-resolution sea surface temperature (SST) record from the western tropical North Atlantic which displays millennial - scale fluctuations during the last glacial. Sedimentation rates are high at the core site due to an influx of riverine suspension loads from the Orinoco and Amazon Rivers, which makes this site well suited for studying suborbital climate variability in the low-latitude Atlantic. The records are also helpful in tracing the temporal relation between lowand high-latitude climate change and to test current concepts of interhemispheric climatic coupling. 


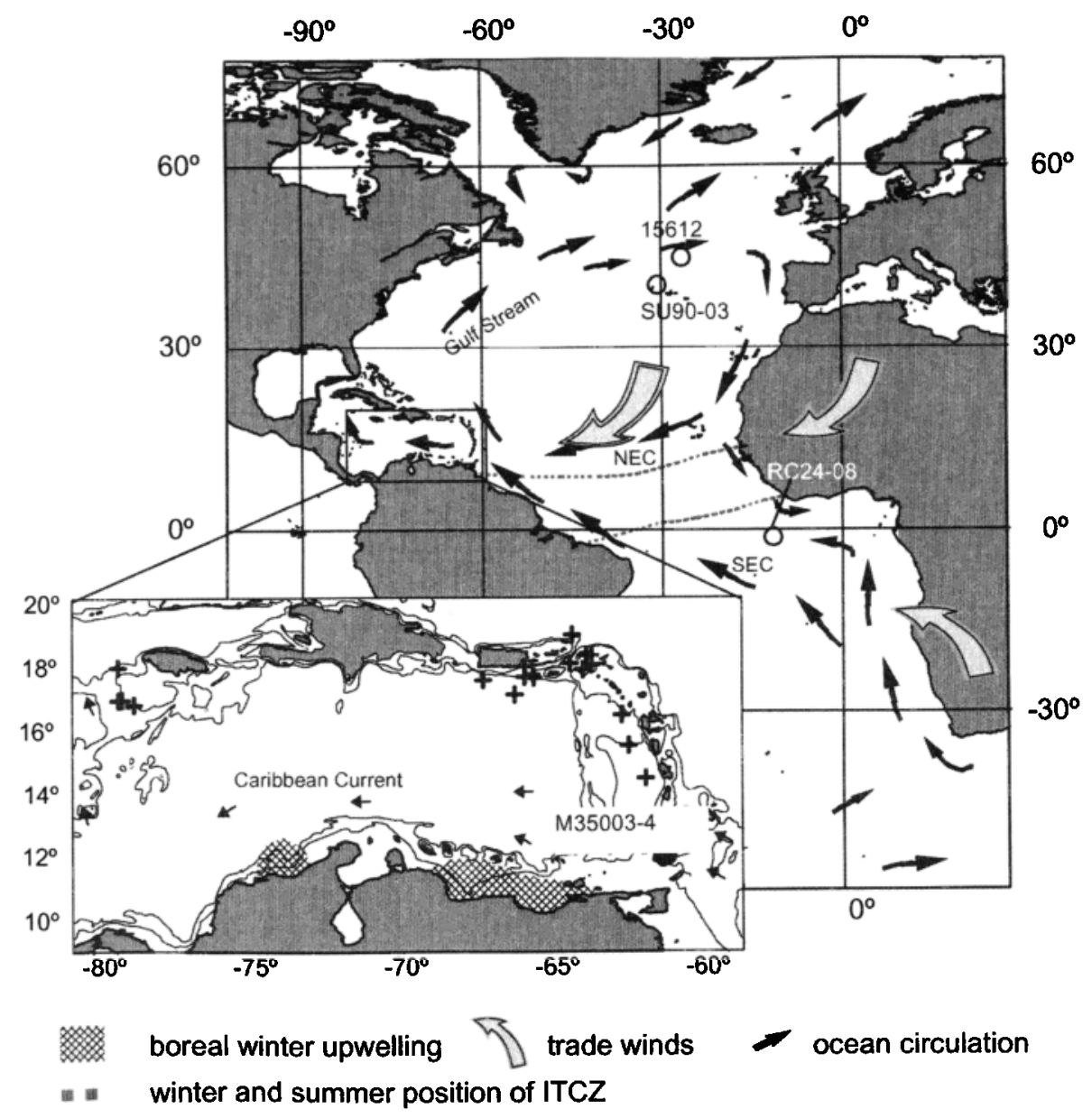

Figure 1. Position of cores and surface samples used in this study. Ocean and atmospheric circulation patterns are after Schott and Molinar [1996], Stramma [1991], Peterson and Stramma [1991], Kinder et al. [1985]. Solid arrows are ocean currents (SEC, South Equatorial Current; NEC, North Equatorial Current; GC, Guayana Current), and shaded arrows are atmospheric trajectories of trades. Bathymetry of the detailed map shows isolines of 1000 and $2000 \mathrm{~m}$ water depth.

\section{Materials and Methods}

\subsection{Core Location and Oceanographic Setting}

Core M35003-4 $\left(12^{\circ} 5.4^{\prime} \mathrm{N}, 61^{\circ} 14.6^{\prime} \mathrm{W}, 1299 \mathrm{~m}\right.$ water depth) was raised at the southern end of the Lesser Antilles island chain, from the western flank of the Tobago Basin immediately east of the island of Grenada. Surface circulation and hydrography in the area are defined by the North Equatorial and North Brazil Currents, which are part of the Atlantic's cross-equatorial surface flow [Stramma and Schott, 1996; Schott and Molinari, 1996]. They carry warm surface waters through the Grenada Passage and other passages along the Lesser Antilles into the Caribbean (Figure 1).

Regional wind regimes undergo distinctive seasonal changes in the course of meridional shifts of the Intertropical Convergence Zone (ITCZ). Trade winds are strongest during boreal winter and spring when the
ITCZ is at its southern position $\left(0^{\circ}-5^{\circ} \mathrm{S}\right)$, thus driving enhanced volumes of warm Atlantic surface waters into the Caribbean. This is the season when coastal upwelling off Venezuela is strongest in response to increased wind-driven Ekman pumping [Kinder et al., 1985; Müller-Karger and Castrot, 1994]. Coastal zone color scanner images also display elevated pigment concentrations which point to an influence of nutrients from Amazon and Orinoco River runoff [Müller-Karger and Castrot, 1994]. During low Orinoco discharge, higher pigment concentrations north of Tobago Island are conceivably associated with nutrients washed from the island or with enhanced phytoplankton productivity due to wind-driven upwelling [Müller-Karger and Castrot, 1994]. During boreal summer and fall the ITCZ is at its northern position $\left(6^{\circ}-10^{\circ} \mathrm{N}\right)$, and trade wind intensity and coastal upwelling off Venezuela are weakest. Elevated phytoplankton pigment concentrations around 
and north of Tobago Island are due to northward advection of Orinoco river suspension [Müller-Karger and Castrot, 1994].

\subsection{Stable Isotopes and ${ }^{14} \mathrm{C}$ Accelerator Mass Spectrometry (AMS) Dating}

Core M35003-4 was sampled at $5 \mathrm{~cm}$ intervals for micropaleontological and stable isotope analyses. All samples were dried at $50^{\circ} \mathrm{C}$ prior to wet sieving. Samples were then washed through a $63 \mu \mathrm{m}$ mesh using tap water. Final washing was done with deionized water to avoid precipitation of tapwater carbonate when drying, which would alter oxygen and carbon isotope ratios. For isotope analysis, three to five benthic foraminiferal specimens were picked from the size fraction $>250 \mu \mathrm{m}$. Preference was given to epibenthic species Cibicidoides wuellerstorfi, C. kullenbergi, and C. pseudoungerianus. In samples below $450 \mathrm{~cm}$, epibenthic species abundances were low, so the endobenthic species Uvigerina peregri$n a$ was used for isotope analysis. Prior to isotope analysis, the samples were ultrasonically rinsed in methanol for $10 \mathrm{~s}$ to clean the foraminifera from coatings of finegrained sediments. Only well-preserved tests with no sediment filling were picked, so that cracking of the foraminiferal tests was not necessary. Isotope samples were transferred to a CARBO KIEL automated carbonate preparation device in which sample $\mathrm{CO}_{2}$ is released in individual glass vials at $70^{\circ} \mathrm{C}$, thus minimizing potential sample-to-sample memory effects. The device is linked online to a FINNIGAN MAT 252 mass spectrometer. Reproducibility for $\delta^{18} \mathrm{O}$ was $0.066^{\circ} \%$ as determined from 80 replicate analysis of an internal carbonate standard (Solnhofen Limestone). All isotope data are referred to the Vienna Pee Dee belemnite (VPDB) scale.

Twelve ${ }^{14} \mathrm{C}$ AMS datings were run on monospecific samples containing between 500 and 1000 tests of Globigerinoides ruber (white variety) (Table 1). Eight additional ${ }^{14} \mathrm{C}$ AMS datings were done on a mixture of tests of $G$. ruber (white variety) and Globigerinoides sacculifer [Rühlemann et al., 1999] (Table 1). The ${ }^{14} \mathrm{C}$ AMS datings were carried out at the Leibniz Laboratory for Isotope Research at Kiel University using a $3 \mathrm{MV}$ Tandetron system. Samples were cleaned with $0.5 \mathrm{ml}$ of $30 \% \mathrm{H}_{2} \mathrm{O}_{2}$ and then evacuated. Sample $\mathrm{CO}_{2}$ for ${ }^{14} \mathrm{C}$ determination was then released using orthophosphoric acid at $80^{\circ} \mathrm{C}$. For detailed description of analytical procedures, see Nadeau et al. [1997] and Schleicher et al. [1998].

Table 1. The ${ }^{14} \mathrm{C}$ AMS Dates and Calendar Years for Core M35003-4

\begin{tabular}{|c|c|c|c|c|c|c|}
\hline Sample & Depth, $\mathrm{cm}$ & Species & $\begin{array}{r}\text { Conventional Age, } \\
\text { years } \\
\end{array}$ & $\begin{array}{r}\text { Error } \pm, \\
\text { years }\end{array}$ & $\begin{array}{r}{ }^{14} \mathrm{C} \text { Age }(-400 \\
\text { years })\end{array}$ & $\begin{array}{r}\text { Calendar Age, } \\
\text { years }\end{array}$ \\
\hline $\mathrm{KIA}_{4693^{a}}$ & 3 & $\begin{array}{l}\text { mixed planktonic } \\
\text { foraminifera }\end{array}$ & 380 & 30 & -20 & 0 \\
\hline KIA5085 $^{a}$ & 98 & G. ruber (pink) & 5300 & 50 & 4900 & 5650 \\
\hline KIA4223 & 110 & G. ruber (white) & 5920 & 40 & 5520 & 6300 \\
\hline KIA $5084^{a}$ & 163 & $\begin{array}{l}\text { mixed planktonic } \\
\text { foraminifera }\end{array}$ & 8480 & 60 & 8080 & 8950 \\
\hline KIA4224 & 190 & G. ruber (white) & 9150 & 50 & 8750 & 9920 \\
\hline KIA 4225 & 225 & G. ruber (white) & 10800 & 90 & 10400 & 12220 \\
\hline KIA4226 & 257.5 & G. ruber (white) & 12220 & 70 & 11820 & 13940 \\
\hline KIA4227 & 290 & G. ruber (white) & 14210 & 90 & 13810 & 15670 \\
\hline KIA4228 & 310 & G. ruber (white) & 16140 & 100 & 15740 & 17410 \\
\hline KIA6973 & 380 & G. ruber (white) & 20260 & 110 & 19860 & 23900 \\
\hline KIA4229 & 420 & G. ruber (white) & 23230 & 210 & 22830 & 26620 \\
\hline KIA4230 & 450 & G. ruber (white) & 25060 & 260 & 24660 & 28660 \\
\hline KIA $4115^{a}$ & 463 & $\begin{array}{l}\text { mixed planktonic } \\
\text { foraminifera }\end{array}$ & 27030 & 220 & 26630 & 29550 \\
\hline KIA $4116^{a}$ & 508 & $\begin{array}{l}\text { mixed planktonic } \\
\text { foraminifera }\end{array}$ & 29480 & 260 & 29080 & 32780 \\
\hline KIA4231 & 542.5 & G. ruber (white) & 30840 & 520 & 30440 & 34824 \\
\hline $\mathrm{KIA} 4117^{a}$ & 563 & $\begin{array}{l}\text { mixed planktonic } \\
\text { foraminifera }\end{array}$ & 32460 & 350 & 32060 & 35710 \\
\hline KIA4118 ${ }^{a}$ & 618 & $\begin{array}{l}\text { mixed planktonic } \\
\text { foraminifera. }\end{array}$ & 36290 & 560 & 35890 & 38443 \\
\hline KIA6974 & 650 & G. ruber (white) & 39680 & 1090 & 39280 & 39230 \\
\hline KIA4232 & 680 & G. ruber (white) & 41200 & 2030 & 40800 & 41300 \\
\hline
\end{tabular}

${ }^{\text {a These }}{ }^{14} \mathrm{C}$ ages are from Rühlemann at al. [1999]. 


\subsection{Planktonic Foraminiferal Census Counts and SST Estimation Procedures}

Planktonic foraminiferal census counts were done on the $>150 \mu \mathrm{m}$ size fraction; a minimum of $300 \mathrm{spec}-$ imens per sample was counted. Forty-three planktonic foraminiferal species and morphotypes were discerned following the taxonomic concepts of Kennett and Srinivasan [1983] and Hemleben et al. [1989]. Intergrades between Neogloboquadrina pachyderma (d) and $N$. dutertrei were identified and labeled as pachyderma / dutertrei (P/D) intergrades [Kipp, 1976]. Globorotalia menardii and $G$. tumida were grouped together [Dawsett and Poore, 1990; Pfaumann et al., 1996].

To estimate SST from fossil assemblages, we use three statistical approaches, the modern analog technique (MAT) of Prell [1985], the transfer function technique (TFT) of Imbrie and Kipp [1971], and a modified version of the transfer function technique introduced by Mix and Morey [1996] and Mix et al. [1999], which we term here TFT* (factors of this function are indicated by superscript asterisk). All methods relate variations of foraminiferal assemblages at a given core location to changes in overlying SST. We use these different procedures to test the sensitivity of our SST estimates to the different statistical approaches. It has been demonstrated that differences exist in SST estimates from MAT and TFT techniques in that MAT captures observed SST from the control data set more accurately than TFT [Prell, 1985; Pflaumann et al., 1996; Gonzalez-Donoso and Linares, 1998]. Furthermore, MAT is less likely to produce erratic SST estimations from no-analog assemblages, i.e., from fossil planktonic assemblages that do not match with any modern assemblage [Hutson, 1977; Prell, 1985].

'MAT, TFT, and TFT* were calibrated to modern SST distribution using a modern reference data set of 750 Atlantic core tops between $65^{\circ} \mathrm{N}$ and $40^{\circ} \mathrm{S}$, which was compiled from published work (Figure 2) [Pflaumann et al., 1996; Imbrie et al., 1990]. Additional data were obtained for this study from 19 core tops from the Caribbean. Core-top foraminiferal census data, factors, were calibrated to SST for caloric winter and summer seasons based on average of SST values at 0,30 , and 50 m $\left(\mathrm{SST}_{0-50 m}\right)$, which were extracted from the World Ocean Atlas [Levitus and Boyer, 1994]. As the core top reference set covers both hemispheres, caloric seasons instead of calendar seasons were used to obtain summer and winter SST (cold, $\mathrm{T}_{c} ;$ warm, $\mathrm{T}_{w}$ ). We also attempt to reconstruct thermocline depths from estimated subsurface temperatures and so calibrated MAT to mean annual temperatures at the 75,100 , and $150 \mathrm{~m}$ depth layers. Seasonal temperature variation at these depths is small so that the use of mean annual water temperature is justified. For subsurface temperature

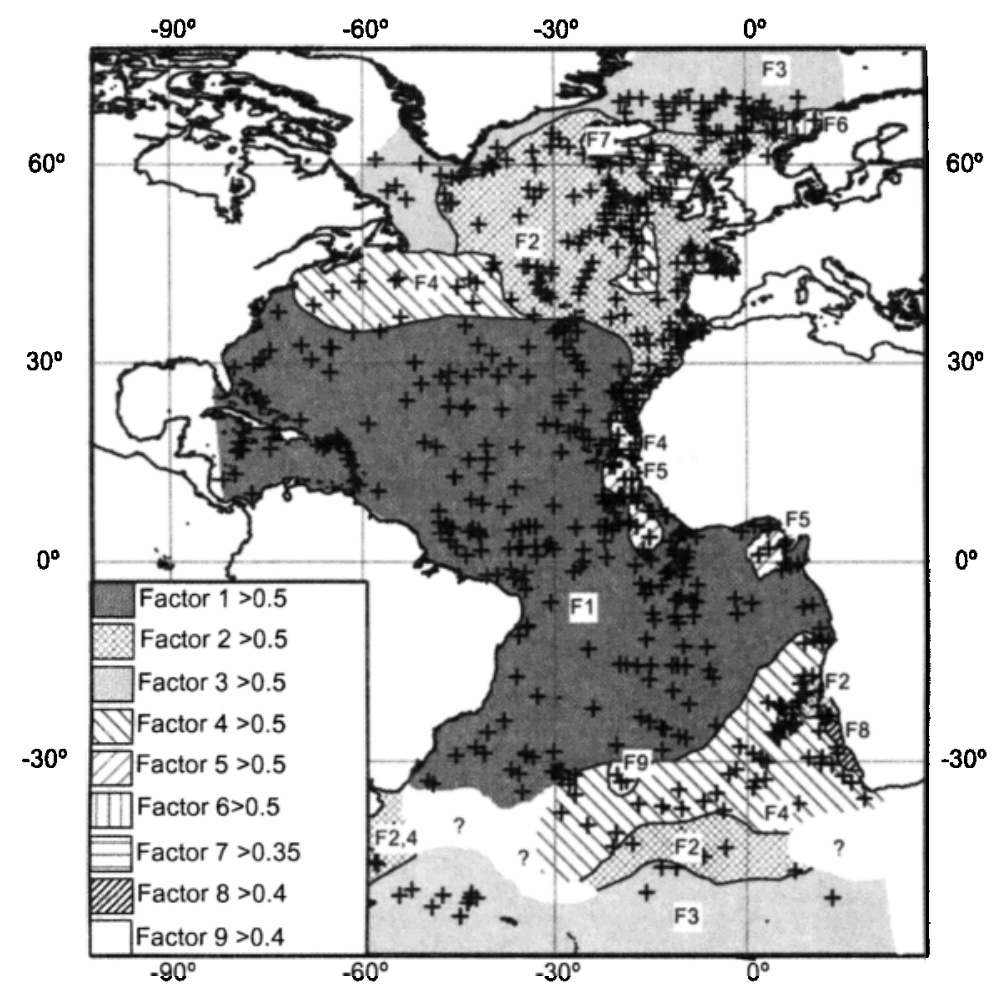

Figure 2. Geographic distribution of nine varimax assemblages from $Q$ mode factor analysis of 750 core tops. Crosses give location of core tops from Pflaumann et al. [1996], Imbrie et al. [1990, SPECMAP Archive 1] and Caribbean core tops (this study). 
Table 2. Varimax Factore Scores Matrix of Factor Model 750-28-9

\begin{tabular}{|c|c|c|c|c|c|c|c|c|c|}
\hline SP. & F1 & F2 & F3 & F4 & F5 & F6 & F7 & F8 & F9 \\
\hline Globigerinella aequilateralis & 0.105 & 0.004 & -0.003 & 0.02 & 0.033 & -0.001 & 0.036 & 0.008 & -0.027 \\
\hline Globige & -0.042 & $0.949^{a}$ & 0.024 & -0.119 & 0.02 & 0.043 & -0.247 & -0.018 & -0.017 \\
\hline Globigerina calida & 0.022 & -0.003 & -0.001 & 0.021 & -0.004 & 0.007 & 0.027 & 0.003 & 0.022 \\
\hline Globorotalia conglobatus & 0.021 & -0.003 & $\mathbf{0}$ & 0.005 & 0.001 & $\mathbf{0}$ & -0.016 & 0 & 0.023 \\
\hline Globorot & 0.011 & -0.005 & $\mathbf{0}$ & 0.018 & 0.07 & -0.009 & 0.006 & 0.014 & 0.008 \\
\hline & 0.001 & -0.002 & $\mathbf{0}$ & 0.002 & 0.028 & -0.004 & 0 & -0.006 & 0.018 \\
\hline Beella & 0.006 & 0.001 & -0.001 & 0.01 & 0.012 & -0.002 & 0.003 & 0 & 0.002 \\
\hline Neglobo & & & -0.009 & -0.001 & $0.547^{a}$ & & 0.036 & $62^{a}$ & 0.048 \\
\hline & 0. & -0 . & -0.01 & 0.166 & 0.035 & -0 & 0.015 & -0.192 & $0.629^{a}$ \\
\hline & & & & & & & $0.897^{a}$ & & 0.007 \\
\hline & 0 . & 0.1 & -0 . & 0 . & -0 & -0 & -0.04 & -0 . & 0.153 \\
\hline & 0 & 0.133 & -0.004 & $a$ & & & & & -0.162 \\
\hline & 0.003 & $\mathbf{0}$ & 0 & -0.001 & -0. & $\mathbf{0}$ & 0.004 & & -0.006 \\
\hline & 0.02 & -0.003 & 0.002 & & & & & -0 . & 0.064 \\
\hline $\mathrm{Ne}$ & 0.007 & -0.043 & $0.979^{a}$ & & -0 . & -0 . & -0.049 & 0. & -0.018 \\
\hline & -0. & & & & & & & & 0.157 \\
\hline & & -0.014 & 5 & -1 & -0 . & -1 & 0.1 & 0. & -0.327 \\
\hline & & 0 & & & & & & & 0.122 \\
\hline & 0 & 0.02 & -0.001 & 1 & -0. & -0 . & 0.026 & & 0.01 \\
\hline $\begin{array}{l}\text { Glo } \\
\text { trilo }\end{array}$ & 0 & 0.0 & -0.004 & 000 & 0 & 0. & -0.11 & 99 & -0.413 \\
\hline $\begin{array}{l}\text { Globigerinoides sacculifer } \\
\text { sacculifer }\end{array}$ & 0.114 & 2 & 003 & 07 & 0.162 & 0.004 & 0.015 & -0.175 & -0.137 \\
\hline & 0.0 & 0 & -0.00 & 0 & 0 & -1 & 0 . & -0. & 0.118 \\
\hline & 0.03 & & & 0.012 & & & & 0.016 & 0.055 \\
\hline$G l$ & & & & & & & & & 0.357 \\
\hline & 0.028 & & & 0.063 & & & 0.021 & & -0.104 \\
\hline ienardii- & 0.07 & -0.035 & 0.009 & 0.012 & $0.689^{a}$ & -0.055 & 0.042 & -0.297 & 0.168 \\
\hline$N . p$ & - & -1 & 0.014 & 0.204 & -0.028 & 0.281 & 0.114 & 3 & 61 \\
\hline Neogloboquadrina pachyderma (d) & -0.023 & -0.018 & .025 & 0.127 & 0.033 & $0.936^{a}$ & -0.037 & 0.045 & 0.032 \\
\hline Cummulative variance & 33.119 & 56.957 & 70.088 & 80.925 & 86.556 & 90.073 & 91.96 & 93.717 & 95.238 \\
\hline
\end{tabular}

aThese numbers indicate high factor scores for characteristic foraminiferal species.

estimations we used the MAT function, which for subsurface temperature estimation was statistically more robust than TFT.

For MAT the squared chord distance as the best index of dissimilarity between fossil and modern assemblages [Overpeck et al., 1985] was used to select the 10 best analogs to derive SSTs from down core samples. The planktonic foraminiferal "factor" model for the classical TFT procedure was developed from the census matrix using Q mode Principle Component Analysis (PCA) [Imbrie and Kipp, 1971; Davis, 1986], which was performed using Fortran routines CABFAC and THREAD [Imbrie and Kipp, 1971; Klovan and Imbrie, 1971]. The Atlantic-wide distribution pattern of the nine factors (Table 2) closely resembles that of earlier factor models (Figure 2) [e.g., Imbrie and Kipp, 1971; Kipp, 1976; Molfino et al., 1982]. The factor model was related to seasonal $\mathrm{SST}_{0-50 m}$ using a stepwise second-degree nonlinear regression analysis (Tables 3 and 4).

The modified transfer function technique of Mix and Morey [1996], which is based on Q-mode factors of downcore planktonic foraminiferal census data of 10 sedimentcores from the tropical Atlantic and Pacific [Mix and Morey, 1996], has been used for comparison. Other than the classical TFT of Imbrie and Kipp [1971], the factor analysis of this modified TFT yields only three principle components, which account for $90 \%$ of the original variance: factor $1^{*}$ (warm tropical assemblage), factor $2^{*}$ (upwelling assemblage), and factor $3^{*}$ (eastern boundary assemblage) [Mix and Morey, 1996; Mix et al., 1999]. We applied this factor model to the down core census data of core M35003-4 and to a geographically restricted $\left(40^{\circ} \mathrm{N}-40^{\circ} \mathrm{S}\right)$ subset of our reference data set from the Atlantic by simple matrix operation using 
Table 3. Correlation Coefficients for TFT Regression Analysis of $\mathrm{SST}_{c 0-50 m}$

\begin{tabular}{lrrrr}
\hline & Coefficient & $\begin{array}{r}\text { Standard } \\
\text { Error }\end{array}$ & $\begin{array}{r}\text { Standard } \\
\text { Coefficient }\end{array}$ & F to Remove \\
\hline Intercept & 10.692 & 0.277 & 10.692 & 1494.024 \\
F1 & 33.969 & 1.817 & 1.813 & 349.358 \\
F3 & -25.206 & 2.153 & -1.103 & 137.048 \\
F4 & 4.484 & 0.396 & 0.153 & 128.092 \\
F5 & 22.273 & 1.788 & 0.643 & 155.127 \\
F8 & -5.776 & 0.745 & -0.101 & 60.152 \\
F1F2 & -14.122 & 0.989 & -0.203 & 203.773 \\
F1F3 & 21.651 & 6.454 & 0.031 & 11.254 \\
F1F4 & -15.11 & 1.124 & -0.206 & 180.847 \\
F1F5 & -22.545 & 1.769 & -0.354 & 162.395 \\
F1F7 & 5.632 & 0.919 & 0.049 & 37.581 \\
F1F9 & -6.811 & 1.102 & -0.073 & 38.18 \\
F2F3 & 8.438 & 1.097 & 0.102 & 59.18 \\
F2F7 & -8.15 & 0.728 & -0.104 & 125.403 \\
F3F6 & 6.463 & 1.111 & 0.056 & 33.857 \\
F3F7 & 10.021 & 2.267 & 0.035 & 19.543 \\
F4F5 & -11.507 & 1.545 & -0.094 & 55.484 \\
F4F8 & 5.674 & 2.013 & 0.035 & 7.944 \\
F5F7 & -16.274 & 3.49 & -0.043 & 21.741 \\
F5F9 & 15.9 & 2.625 & 0.055 & 36.702 \\
F6F7 & -14.007 & 1.91 & -0.054 & 53.757 \\
F6F9 & -9.922 & 3.591 & -0.02 & 7.636 \\
F7F8 & -15.895 & 3.707 & -0.034 & 18.386 \\
F7F9 & -14.821 & 5.66 & -0.021 & 6.856 \\
F1 & -18.501 & 1.652 & -0.959 & 125.405 \\
F3 & 17.659 & 2.029 & 0.73 & 75.778 \\
F5 & -10.343 & 1.5 & -0.205 & 47.539 \\
\hline
\end{tabular}

the THREAD Fortran routine. Seasonal SST functions for the upper $50 \mathrm{~m}$ are developed by using a stepwise second- degree nonlinear regression analysis:

$$
\begin{array}{r}
T_{c}=16.05+5.55 f_{1}^{*}-19.39 f_{3}^{*}+6.37 f_{1}^{* 2} \\
+5.49 f_{2}^{* 2}+21.13 f_{3}^{* 2} \\
T_{w}=20.24+8.58 f_{1}^{*}-18.84 f_{2}^{*}+15.94 f_{1}^{*} f_{2}^{*} \\
-15.04 f_{1}^{*} f_{3}^{*}+14.63 f_{2}^{* 2}+7.64 f_{3}^{* 2}
\end{array}
$$

where $T_{w}$ and $T_{c}$ are warm and cold seasonal temperatures, respectively, and $f_{1}^{*}$ to $f_{3}^{*}$ are the loadings of the factors 1,2 and 3 , respectively. $\mathrm{SST}_{0-50 m}$ estimates from MAT and TFT are highly correlated with observed SST, with correlation coefficients $>0.9$ (Figure 3a). A higher accuracy for MAT-derived $\mathrm{SST}_{0-50 m}$ estimates is indicated by lower standard deviations of the residuals (estimated minus observed SST). The correlation between estimated and measured $\mathrm{SST}_{0-50 \mathrm{~m}}$ using the TFT* approach in conjunction with the regionally restricted core top data set $\left(40^{\circ} \mathrm{N}-40^{\circ} \mathrm{S}\right)$ is weaker

\footnotetext{
${ }^{1}$ supporting data are available electronically at Pangaea database (URL://www.pangaea.de/Institutes/GEOMAR/).
}

than that of $\mathrm{SST}_{0-50 m}$ derived from the classic TFT, which includes high-latitude core top samples for calibration (Figure $3 \mathrm{~b}$ ). The lower statistical robustness of $\mathrm{TFT}^{*}$ obviously is a response to the lower total range in SST of the reference data set $\left(40^{\circ} \mathrm{N}-40^{\circ} \mathrm{S}\right)$, pointing to other environmental factors influencing planktonic foraminiferal faunas, such as thermocline depth and nutrient availability [Ravelo et al., 1990; Andreason and Ravelo, 1997; Ravelo and Andreason, 1999]. Correlation between estimated subsurface temperatures at 75,100 , and $150 \mathrm{~m}$ water depth and observed temperatures is high $(>0.9$; Figure 4$)$, close to that of the MAT-SST ${ }_{0-50 m}$ estimates.

\section{Results}

\subsection{Stratigraphy and Age Model}

The benthic $\delta^{18} \mathrm{O}$ record ${ }^{1}$ (Figure 5) shows the last glacial-interglacial transition between 200 and $300 \mathrm{~cm}$ core depth; isotope stage $3 / 2$ boundary is displayed in a $\delta^{18} \mathrm{O}$ increase at $450 \mathrm{~cm}$ core depth. Two $\delta^{18} \mathrm{O}$ minima at 900 and $945 \mathrm{~cm}$ are taken here as correlatives to marine isotope substages 3.31 and 3.33 at 50 and $55 \mathrm{kyr}$ [Martinson et al., 1987]. The end of the Last Glacial Maximum (LGM) is indicated by an abrupt decrease in 
Table 4. Correlation Coefficients for TFT Regression Analysis of $\mathrm{SST}_{w 0-50 m}$

\begin{tabular}{lrrrr}
\hline & Coefficient & $\begin{array}{r}\text { Standard } \\
\text { Error }\end{array}$ & $\begin{array}{r}\text { Standard } \\
\text { Coefficient }\end{array}$ & F to Remove \\
\hline Intercept & 18.448 & 0.453 & 18.448 & 1655.043 \\
F1 & 27.011 & 1.92 & 1.551 & 197.824 \\
F2 & -3.702 & 0.478 & -0.18 & 59.984 \\
F3 & -30.589 & 2.337 & -1.441 & 171.387 \\
F5 & 11.424 & 1.345 & 0.355 & 72.114 \\
F1F2 & -9.176 & 1.168 & -0.142 & 61.693 \\
F1F3 & 26.54 & 6.389 & 0.041 & 17.257 \\
F1F4 & -11.217 & 0.899 & -0.165 & 155.515 \\
F1F5 & -12.319 & 1.459 & -0.208 & 71.324 \\
F1F7 & 5.447 & 0.854 & 0.051 & 40.659 \\
F2F3 & 11.773 & 1.221 & 0.153 & 92.942 \\
F2F4 & 3.887 & 0.664 & 0.071 & 34.317 \\
F2F7 & -8.472 & 0.804 & -0.116 & 111.023 \\
F3F4 & 7.741 & 1.696 & 0.047 & 20.836 \\
F3F6 & 6.835 & 1.21 & 0.064 & 31.897 \\
F3F7 & 13.614 & 2.366 & 0.052 & 33.12 \\
F5F9 & 7.416 & 2.376 & 0.027 & 9.742 \\
F6F7 & -13.978 & 1.896 & -0.058 & 54.356 \\
F6F9 & -14.313 & 3.509 & -0.031 & 16.642 \\
F7F8 & -20.096 & 3.346 & -0.046 & 36.069 \\
F12 & -17.597 & 1.662 & -0.981 & 112.147 \\
F32 & 18.305 & 2.206 & 0.814 & 68.834 \\
F52 & -7.755 & 1.248 & -0.165 & 38.631 \\
F62 & -1.553 & 0.725 & -0.024 & 4.59 \\
F72 & -4.235 & 1.799 & -0.025 & 5.54 \\
F82 & -5.568 & 1.351 & -0.042 & 16.977 \\
\hline & & & &
\end{tabular}

$\delta^{18} \mathrm{O}$ by $0.9^{\circ} \%$ at $290 \mathrm{~cm}$ core depth. An age of 13.8 ${ }^{14} \mathrm{C}$ kyr (15.7 calendar kyr) indicates that this event is coeval with North Atlantic "Heinrich" event H1. The Younger Dryas climatic rebound is displayed in only a small increase in benthic $\delta^{18} \mathrm{O}$ between 210 and $240 \mathrm{~cm}$ at a ${ }^{14} \mathrm{C}$ age of $10.4 \mathrm{kyr}$ at $225 \mathrm{~cm}$ (equivalent to 12.2 calendar kyr).

An initial age scale was developed by interpolating between the ${ }^{14} \mathrm{C}$ age fix points. The radiocarbon timescale was then converted into a calendar year time scale by using the CALIB conversion routine [Stuiver and Reimer, 1993; Stuiver et al., 1998] for ${ }^{14} \mathrm{C}$ ages younger than $20 \mathrm{kyr}$. The older ${ }^{14} \mathrm{C}$ ages were converted applying age shifts given in Laj et al. [1996] (Table 1).

The age model was fine-tuned through stratigraphic correlation of faunal data and carbonate records of core M35003-4 to the Greenland Ice Sheet Project 2 (GISP2) $\delta^{18} \mathrm{O}$ record (Figure 6). During stage 3 the abundance of $N$. dutertrei and the carbonate record display rapid fluctuations that are markedly similar to Dansgaard/Oeschger variability in the ice core record (Figure 7). The triplet of $N$. dutertrei maxima and $\mathrm{CaCO}_{3}$ minima between 498 and $548 \mathrm{~cm}$ core depth and the slightly broader maximum immediately below closely mirror the sequence of interstadials 8-5 (37-32 calendar kyr) in the ice core record. Likewise, the two broad $N$. dutertrei maxima which run along with two broad carbonate minima at $670-730 \mathrm{~cm}$ and $760-830 \mathrm{~cm}$ core depth mirror interstadials 12-9, and 14-13. Benthic foraminiferal $\mathrm{Cd} / \mathrm{Ca}$ maxima at $300,380,460$, and $650 \mathrm{~cm}$ core depth in core M35003-4 [Stüber, 1999; R. Zahn and A. Stüber, manuscript in preparation, 2000) reflect ventilation minima during "Heinrich" events H1$\mathrm{H} 4$. Using the ages of corresponding full stadials in the GISP2 record, the $\mathrm{Cd} / \mathrm{Ca}$ anomalies are used as additional age markers at $15.7 \mathrm{kyr}(\mathrm{H} 1), 23.9 \mathrm{kyr}(\mathrm{H} 2), 29.3$ kyr (H3), and $392 \mathrm{kyr}$ (H4).

The age model yields shifts between ${ }^{14} \mathrm{C}$ and calendar years of 0-1.5 kyr at 40 calendar kyr, increasing to $4 \mathrm{kyr}$ at 30 calendar kyr and decreasing again to 2 kyr during Termination I and $0.5 \mathrm{kyr}$ in the mid-Holocene (Table 1). This pattern closely tracks the evolution of the ${ }^{14} \mathrm{C}$ offset from calendar years over the past 50 calendar kyr. [Laj et al., 1996; Völker et al., 1998]. Sedimentation rates vary between 10 and $48 \mathrm{~cm}$ per 1000 years, yielding a temporal resolution of $300-500$ years at $5 \mathrm{~cm}$ sampling intervals.

\subsection{Planktonic Foraminiferal Assemblage Variations}

Abundances of warm-water species, e.g., G. ruber and $G$. sacculifer trilobus, and of the tropical species 


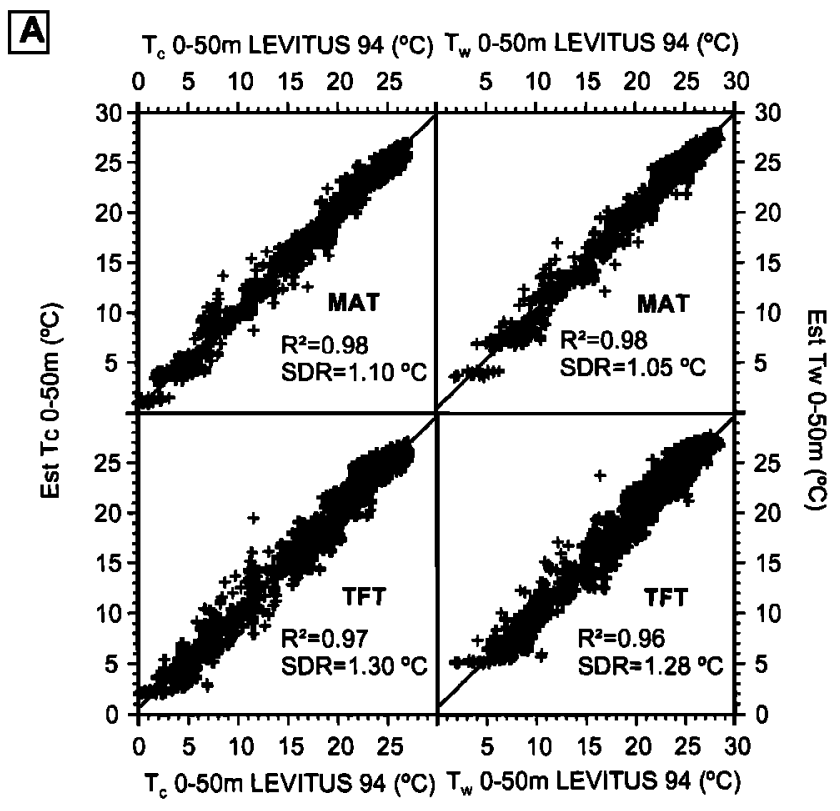

B.

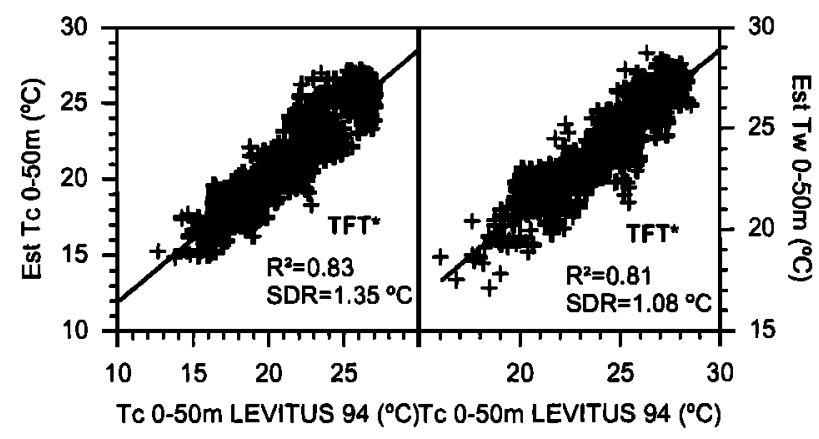

Figure 3. (a) Estimated versus measured sea surface temperature (SST) $(0-50 \mathrm{~m}$ water depth, Levitus and Boyer [1994]) using the modern calibration data set between $65^{\circ} \mathrm{N}$ and $60^{\circ} \mathrm{S}$ and applying modern anaolog technique (MAT) and transfer function technique (TFT) (Prell [1985], Imbrie and Kipp [1971]); (b) Same as in Figure 3a, except for modern calibration data set between $40^{\circ} \mathrm{N}$ and $40^{\circ} \mathrm{S}$ and applying the TFT* approach of $M \imath x$ et al. [1999].

group G. menardii-tumida are decreased in glacial core sections, whereas high-latitude "cold" faunal components like $G$. bulloides are increased (Figure 7). $G$. bulloides is most abundant in the modern Caribbean during seasonal upwelling off Venezuela [Peterson et al., 1991; DeMiro, 1971). N. dutertrei which today dwells in the thermocline near the deep chlorophyll maximum [Sautter and Thunell, 1991, Fairbanks et al., 1982] shows maximum abundances during stage 3 , with millennial - scale variability comparable to the Dansgaard/Oeschger cycles seen in Greenland icecores. Polar species $N$. pachyderma (sinistral) contributes up to $12 \%$ to the total planktonic assemblage during stages
2 and 3. The occurrence of this species outside polar waters is typically associated with upwelling regimes [Ufkes and Zachariassee, 1993; Giradeau and Rogers, 1994; Little et al., 1997; Ufkes et al., 1998; Ivanova et al., 1999).

A two-step change in assemblage structure is observed, coinciding roughly with isotope stage boundaries $3 / 2$ and $2 / 1$ (Figure 8 a). During stage 3 , factor loadings of the tropical assemblage (factor 1) are low with values between 0.7 and 0.8 . Loadings of highlatitude subpolar and polar factors 2 and 3, of equa-
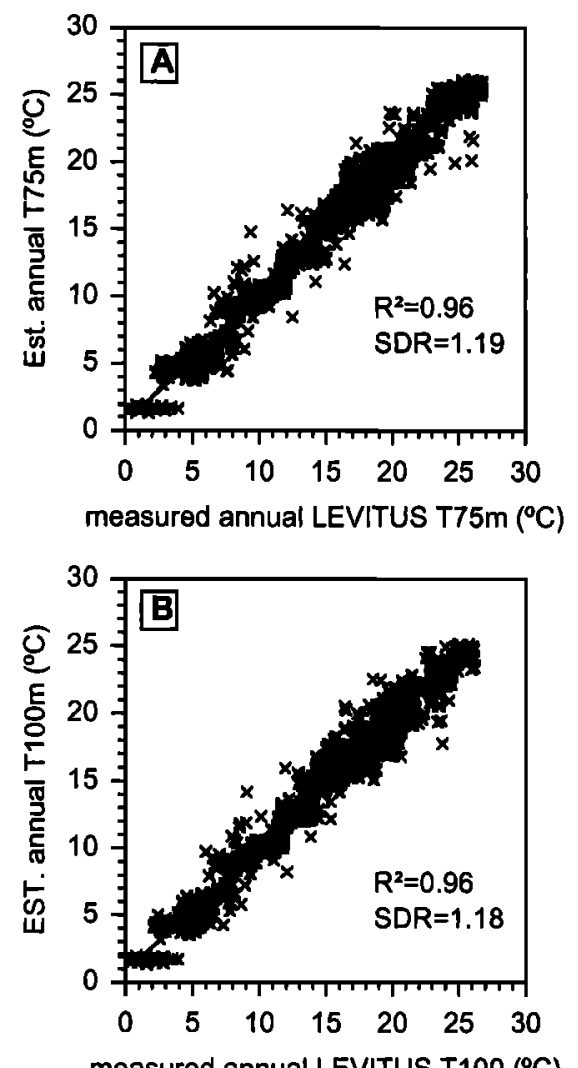

measured annual LEVITUS T100 $\left({ }^{\circ} \mathrm{C}\right)$



Figure 4. Statistics for subsurface MAT temperature estimation. Correlation between estimated and measured mean annual temperature at (a) 75, (b) 100, and (C) $150 \mathrm{~m}$.water depth. 


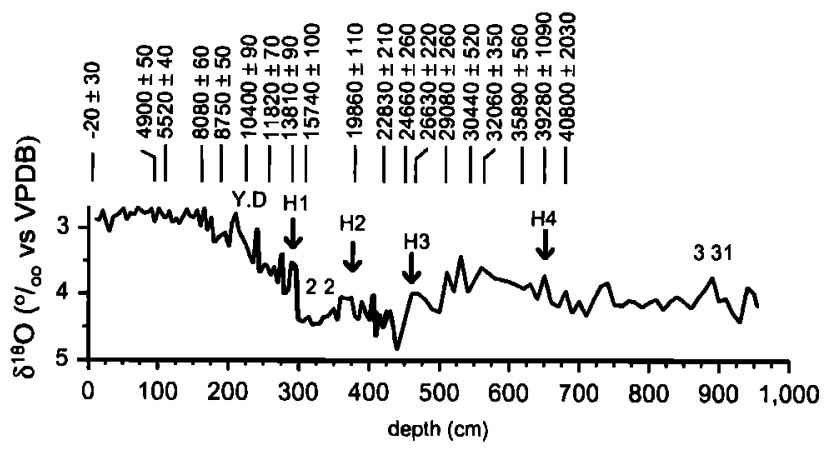

Figure 5. Benthic $\delta{ }^{18} \mathrm{O}$ record of M35003-4. The upper part of the isotope record $(0-420 \mathrm{~cm})$ has been measured on $C$. wuellerstorfi, C. kullenbergi, and C. pseudoungerianus. For the lower part of the record, Uvigerina spp. has been used because of low abundances of Cibıcidoides spp. The isotope data are plotted on the Uvigerina scale of $\delta{ }^{18} \mathrm{O}$; Cibrcidordes has been converted to the Uvigerina scale by adding $0.64^{\circ} \%$ o [Duplessy et al., 1984]. Position and ages (reservoir-corrected kiloyears) of radiocarbon data are shown on top. "Heinrich" events $\mathrm{H} 1-\mathrm{H} 4$ are used as additional age markers and are inferred from benthic $\mathrm{Cd} / \mathrm{Ca}$ anomalies in this core [Stüber, 1999; Zahn and Stüber, manuscript in preparation, 2000], which resulted from convection slow down and nutrient build up during these episodes (see also Willamowski and Zahn [2000]). torial gyre margin factor 5 and upwelling factor 8 are increased. Near isotope stage boundary $3 / 2$, abundances of the tropical assemblage (factor 1) increase to nearly Holocene levels, whereas polar-subpolar assemblages (factors 2 and 3 ) as well as gyre margin (factor 5) and South Atlantic coastal upwelling assemblages (factor 8) decrease. A second change in assemblage structure occurs during Termination I when the polar-subpolar assemblage (factors 2 and 3) gradually decreases and finally disappears entirely from the faunal record in the early Holocene.

Using the modified down core factor model of $\mathrm{Mix}$ and Morey [1996] and Mix et al. [1999], planktonic foraminiferal variability in core M35003-4 is dominated by fluctuations of the tropical (factor $1^{*}, G$. ruber and $G$. sacculifer) and the upwelling assemblage (factor $2^{*}$, $N$. dutertrei and $G$. bulloides) (Figure 8b). Higher abundances of $\mathrm{f} 2 *$ occur during stage 3 , with maxima during North Atlantic warm interstadials (IS) 14-5.

\subsection{SST Estimates}

Except for the $150 \mathrm{~m}$ water depth level, estimated seasonal SSTs (0-50 $\mathrm{m}$ and subsurface) at the top of the core reproduce observed temperatures to within $1^{\circ} \mathrm{C}$

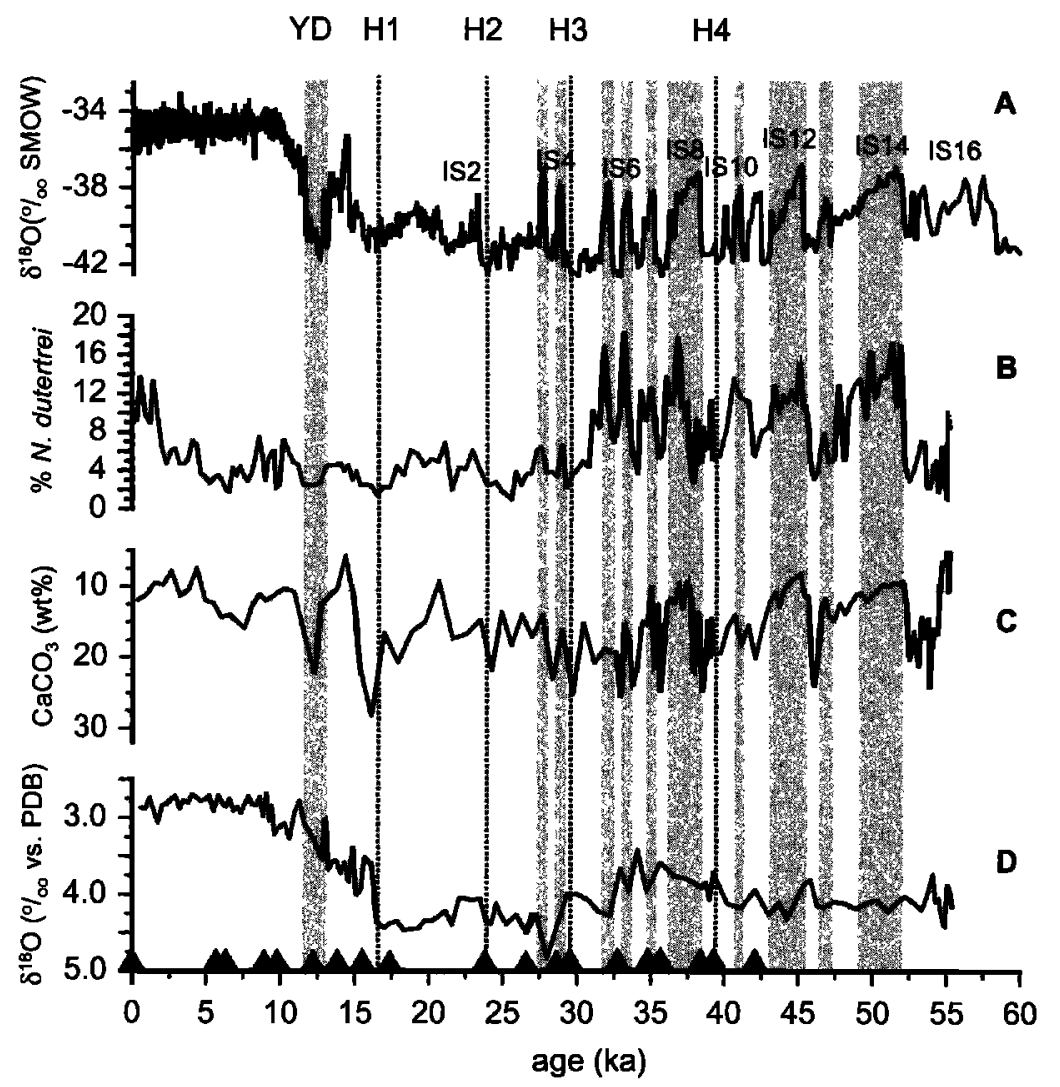

Figure 6. Age model for core M35003-4, correlation to the GISP 2 ice core. (a) $\delta{ }^{18} \mathrm{O}_{\imath c e}$ of GISP2 [Grootes and Stuiver, 1997]; (b) abundance of $N$. dutertrel; (c) carbonate content; (d) benthic $\delta{ }^{18} \mathrm{O}$ record. Triangles give positions of ${ }^{14} \mathrm{C}$ data along core M35003-4. Vertical dashed lines indicate position of benthic $\mathrm{Cd} / \mathrm{Ca}$ anomalies, which are used as markers for Heinrich events [Stüber, 1999; Stüber and $Z a h n$, manuscript in preparation, 2000]. 


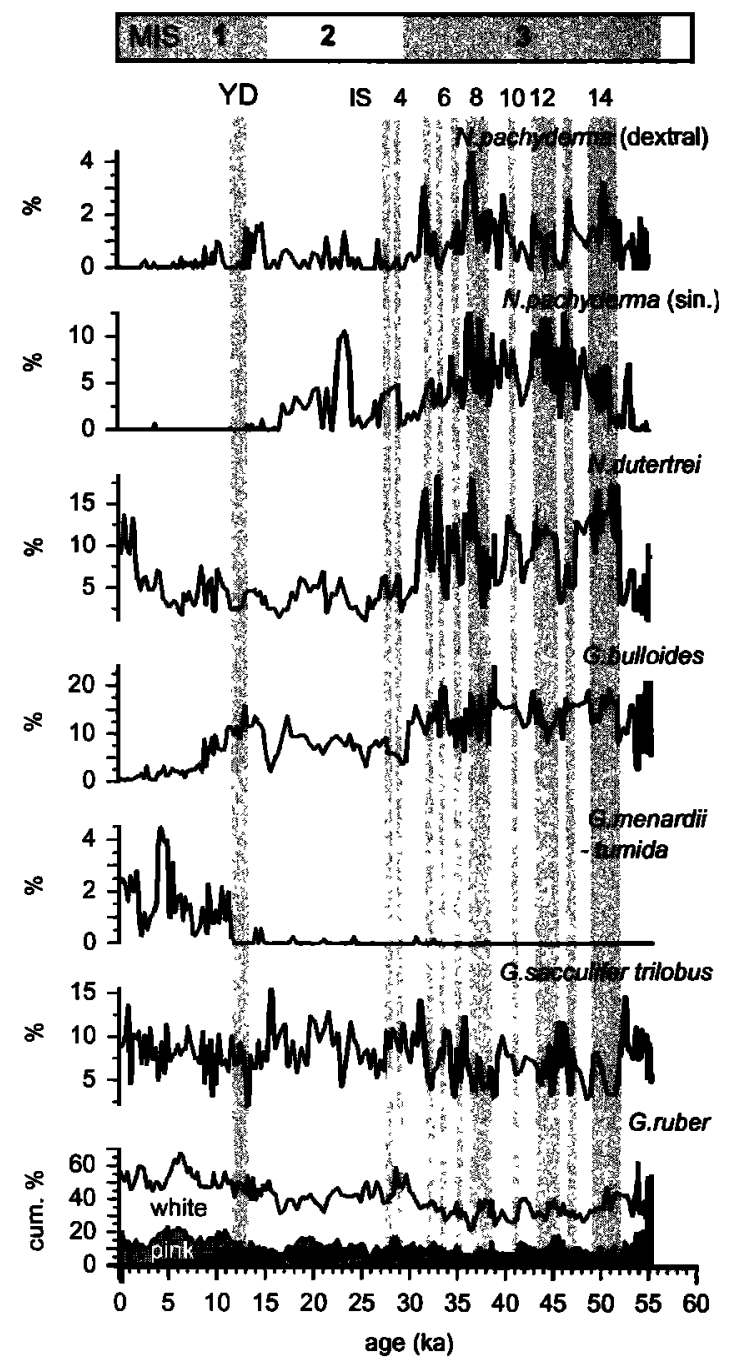

Figure 7. Distribution of characteristic planktonic foraminiferal species along core M35003-4.

(Figure 9). Estimated mean annual temperature at $150 \mathrm{~m}$ is $\sim 1.5^{\circ} \mathrm{C}$ warmer than observed temperatures. This offset is likely caused by the presence of oceanic fronts which are associated with the regional upwelling system. Coldest surface and subsurface temperatures are inferred for glacial stage $3 . \mathrm{SST}_{0-50 m}$ is between $23^{\circ}$ (cold season, $\mathrm{T}_{c}$ ) and $25^{\circ} \mathrm{C}$ (warm season, $\mathrm{T}_{w}$ ), $3^{\circ}$ $2.5^{\circ} \mathrm{C}$ colder than Holocene SST. At the same time, mean subsurface temperatures are between $15^{\circ}(150 \mathrm{~m})$ and $18^{\circ} \mathrm{C}(75 \mathrm{~m})$. Subsurface cooling at 75 and $150 \mathrm{~m}$ water depth as is indicated by our estimates reflects a shoaling of the thermocline and thinning of the mixed layer. At stage boundary $3 / 2, \mathrm{SST}_{0-50 m}$ increases to $25^{\circ}\left(\mathrm{T}_{c}\right)$ and $27^{\circ} \mathrm{C}\left(\mathrm{T}_{w}\right)$, followed by a slight temperature decrease into late stage 2 . Minimum SST immediately before $\mathrm{H} 1$ is $22.5^{\circ}\left(\mathrm{T}_{c}\right)$ and $25^{\circ} \mathrm{C}\left(\mathrm{T}_{w}\right)$; warming during Termination $\mathrm{I}$ is $2.5^{\circ} \mathrm{C}$.
Comparison with our factor model 750-28-9 and the tropical glacial down core model of Mix and Morey [1996] and Mix et al. [1999] (Figure 8) shows that the inferred rapid temperature changes are mainly driven by the interplay between tropical-subtropical faunal elements at the warm side $\left(\mathrm{f} 1 ; \mathrm{f1}{ }^{*}\right)$ and upwelling indicating assemblages at the cold side ( $f 2, \mathrm{f} 3, \mathrm{f} 8 ; \mathrm{F} 2^{*}$ ). Most dominant structures are warm events with a duration of 3-5 kyr which are separated by short-lived cooling events where $\mathrm{SST}_{0-50 m}$ decreases by $2^{\circ}-4^{\circ} \mathrm{C}$. During Heinrich events, SST trends go from short cooling during $\mathrm{H} 4$ and $\mathrm{H} 2$ to warming during $\mathrm{H} 3$ and $\mathrm{H} 1$. During the Younger Dryas, SSTs are $\sim 0.5^{\circ}-1^{\circ} \mathrm{C}$ warmer than immediately before and after this event.

The accuracy of MAT SST estimates can be evaluated by using the similarity measure and the temperature range of selected best analogs (Figures 9d-9f). Similarity decreases from Holocene values above 0.95 to glacial values between 0.85 and 0.9 . A lower similarity during the last glacial and Termination I is accompanied by increased standard deviations of SST from selected best analogs, indicating a lower precision of SST estimates at these times.

The SST records from MAT, TFT, and $\mathrm{TFT}^{*}$ all yield similar trends and fine-scale structures but are offset in absolute SST levels. During the last glacial, SST estimates from TFT are offset by $1.5^{\circ}-3.0^{\circ} \mathrm{C}$ (Figure 10). A possible explanation for this discrepancy is the co-occurrence in glacial samples of core M35003-4 of tropical/subtropical and polar/subpolar faunas; such faunal patterns are not observed in core top samples of the modern control data set so that the glacial samples contain no-analog faunas. MAT recognizes this situation in that it shows for these samples lower similarities relative to selected best modern analogs. The classical TFT still displays high communalities on the same level as in the Holocene, above 0.9, indicating that the TFT factor model does not recognize the glacial assemblages as no-analogs. The lower glacial similarities in MAT go along with increased standard deviations of computed SST, indicating that glacial SSTs are derived from a larger range of SSTs at the locations of core tops, which are selected as the closest representatives of glacial assemblages (Figures 9d-9f). SST estimates from TFT* are close to MAT estimates within the precision of both methods $\left(1^{\circ} \mathrm{C}\right)$; during stage 3 both methods give nearly identical estimates. However, during early stage 2 and the late deglaciation, $\mathrm{SST}_{\mathbf{0}-50 m}$ from MAT and $\mathrm{TFT}^{*}$ are offset by $1.5^{\circ}-2^{\circ} \mathrm{C}$.

It is important to note that even though the different techniques and functions yield slightly different absolute temperature estimates, the SST records all follow the same trend and pattern. This obviously is the result of the down core patterns of faunal variability which are the common input to the different methods. Therefore 

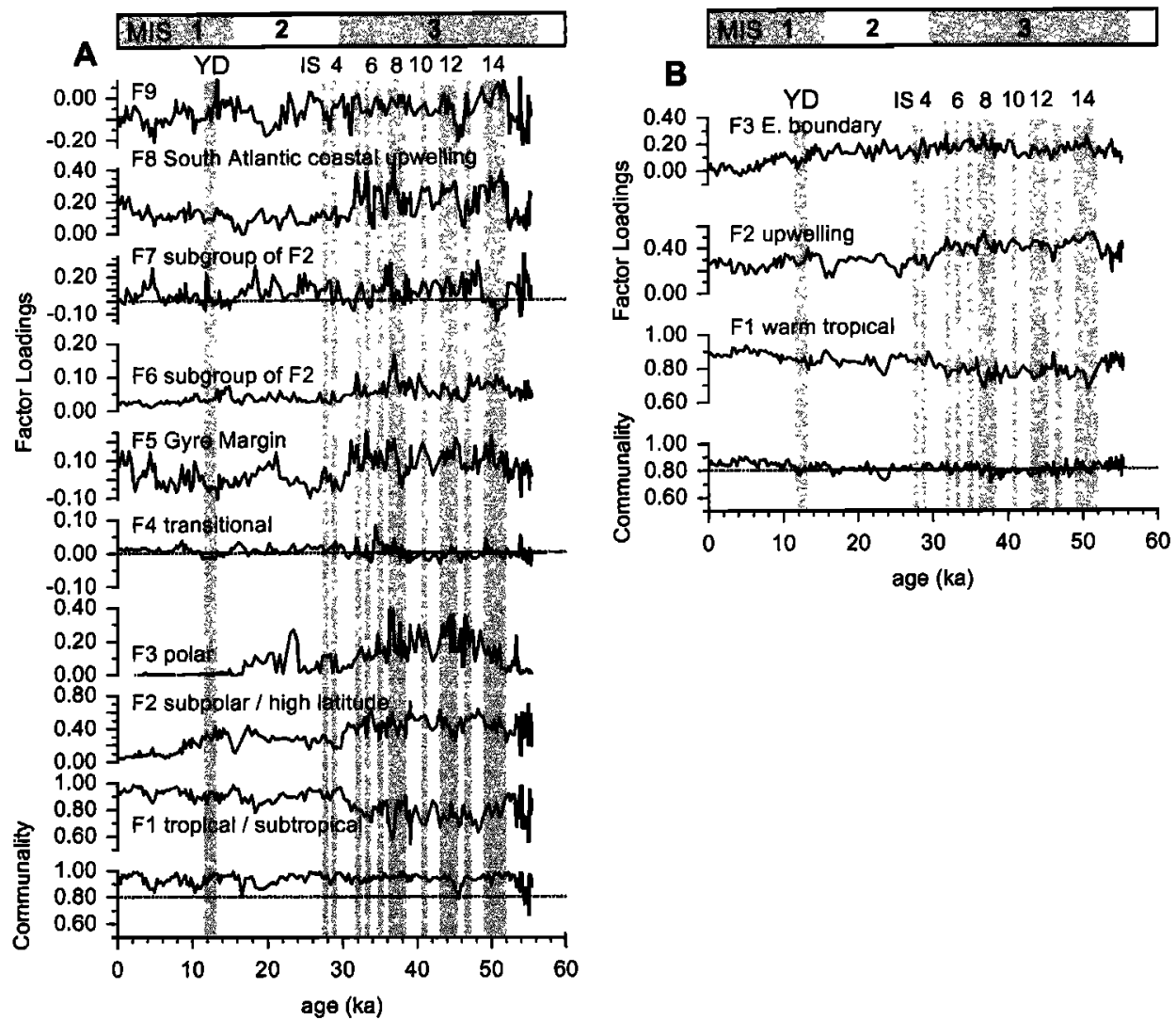

Figure 8. Variability of communality and varimax (factor) assemblages of core M35003-4. (a) F1-F9 (factor model 750-28-9; see also Table 2); (b) F1*-F3* from the TFT* approach of Mix et al. [1999].

the conclusions drawn from our records remain valid as they not so much depend on absolute SST estimates but they primarily build on the trend and patterns of SST variation and variability.

\section{Discusssion}

\subsection{Dissolution Effects on SST Estimates}

An important observation in our records is the existence of millennial-scale faunal fluctuations during the last glacial which, are particularly well developed during isotope stage 3 (Figures 7 and 8 ). It is important to determine if this faunal variability documents true environmental variability at this low-latitude location or if it is an artefact from post-depositional alteration, e.g., by carbonate dissolution. Potential sources for changes in carbonate preservation are rapid changes between carbonate-saturated and carbonate-corrosive waters in response to varying rates of mid depth ventilation [e.g., Marchitto et al., 1998; Oppo et al., 1995; Boyle and Keigwin, 1987]. If this caused rapid carbonate dissolution cycles, the varying state of preservation and loss of fragile planktonic shells from warm-water species, e.g., G. ruber or G. sacculifer, would result in erroneous SST cycles at the pace of millennial-scale oscillations [Berger, 1968, 1970; Le and Thunell, 1996].

To evaluate the possible influence of selective carbonate dissolution on the distribution of planktonic foraminiferal abundances and inferred SST, we generated records of carbonate and silt fraction $(<63 \mu \mathrm{m})$ contents, high-magnesium-calcite (percent HMC), benthic foraminiferal abundances, and planktonic foraminiferal fragmentation (percent FRGM wich equals fragments times [whole plus fragments] ${ }^{-1}$ times 100) along core M35003-4 (Figure 11). Carbonate content and percent FRGM for the most part of the records are in antiphase, in that maxima in percent FRGM correlate with minima in carbonate content (Figures $11 \mathrm{~b}$ and 11d) thus being indicative of carbonate dissolution cycles. This pattern is particularly well developed during stage 3 when fragmentation shows a quasi-cyclical distribution and reaches up to $50 \%$ in sections with minimum carbonate content. Elevated abundances of benthic foraminifera (Figure 11e) conceivably document high organic fluxes to the seafloor [Herguera and Berger, 1991]. Though there is some indication for varying states of carbonate dissolution along core M35003-4, the correlation between inferred state of carbonate preser- 


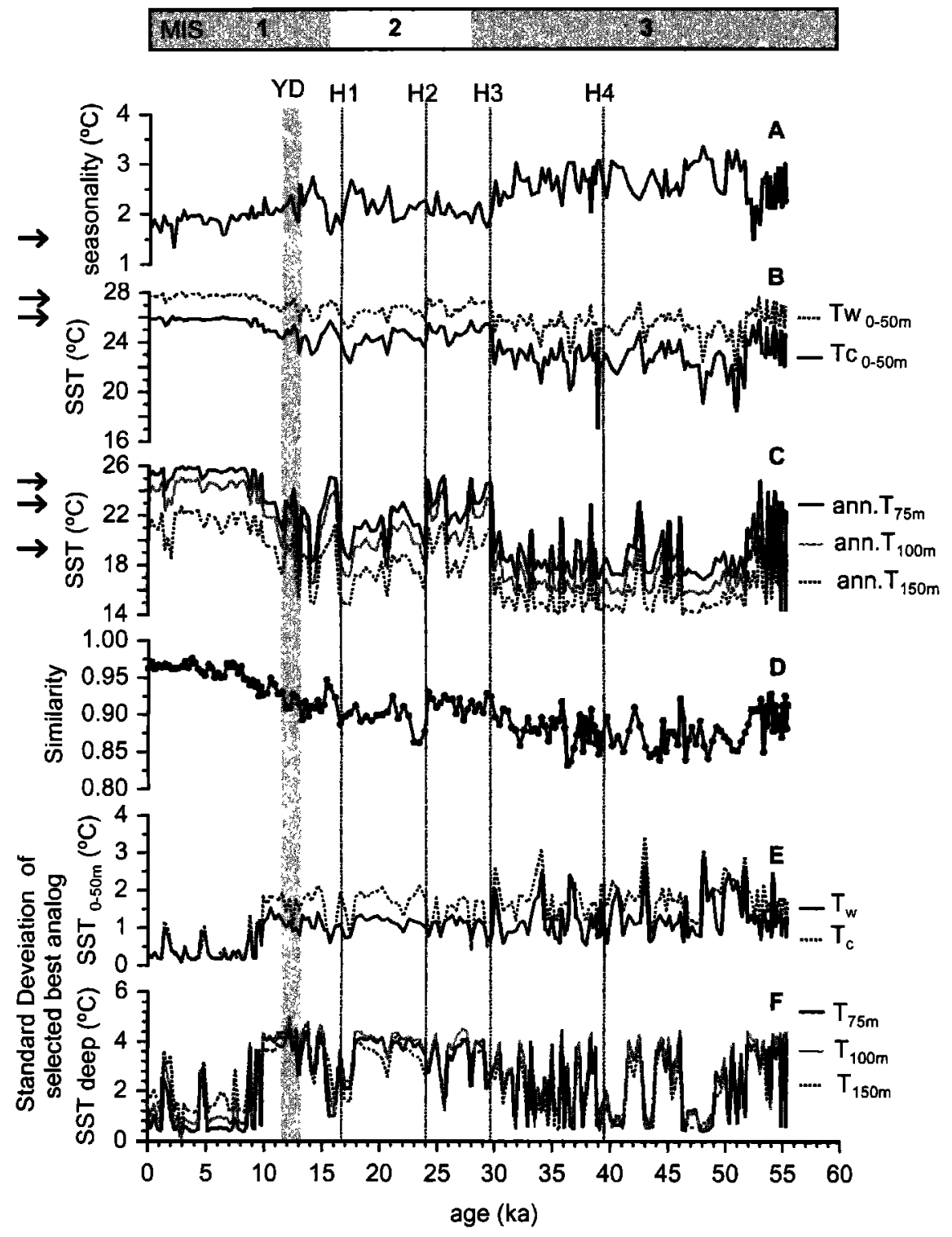

Figure 9. MAT SST estimates for core M35003-4. (a) Estimated seasonality; (b) warm $\left(\mathrm{T}_{w}\right.$ ) and cold $\left(\mathrm{T}_{c}\right.$ ) season $\mathrm{SST}_{0-50 m}$ estimates; (c) annual $\mathrm{SST}_{75 m}-\mathrm{SST}_{150 \mathrm{~m}}$ estimates; (d) similarity measure; (e) standard deviation of $\mathrm{SST}_{0-50 m}$ from selected best analogs; (f) standard deviation of $\mathrm{SST}_{75 m-150 m}$ from selected best analogs. Arrows in Figures 9a-9c indicate modern temperature levels.

vation and SST is not tight. Maxima in foraminiferal fragments at 53,45 , and 37 calendar kyr, for instance, do not correlate with SST decreases. We thus conclude that millennial-scale SST variability which is observed along core M35003-4 is not an artefact of carbonate dissolution but represents true millennial-scale surfaceocean variability in the Tobago Basin.

\subsection{Subtropical SST Variability: Possible Causes and Implications}

4.2.1. Local Upwelling. Changes of wind-driven upwelling in the Tobago Basin would be a viable means to drive the reconstructed glacial-interglacial and mil- lennial - scale SST variations seen in core M35003-4. Higher input of eolian sediments into the tropical Atlantic as well as increased productivity in the equatorial Atlantic are indicative of enhanced zonal wind intensity during the last glacial [Ruddiman, 1997; McIntyre et al., 1989; McIntyre and Molfino, 1996]. Increased wind intensity was presumably caused by a southward shift of the ITCZ in conjunction with an equatorward compression of climatic belts [Mix et al., $1986 \mathrm{a}, 1986 \mathrm{~b}$; Hostetler and Mix, 1999]. A more southern position of the ITCZ may have stimulated stronger upwelling off Venezuela with an expansion of the upwelling cells to the north, as has been inferred previously from en- 

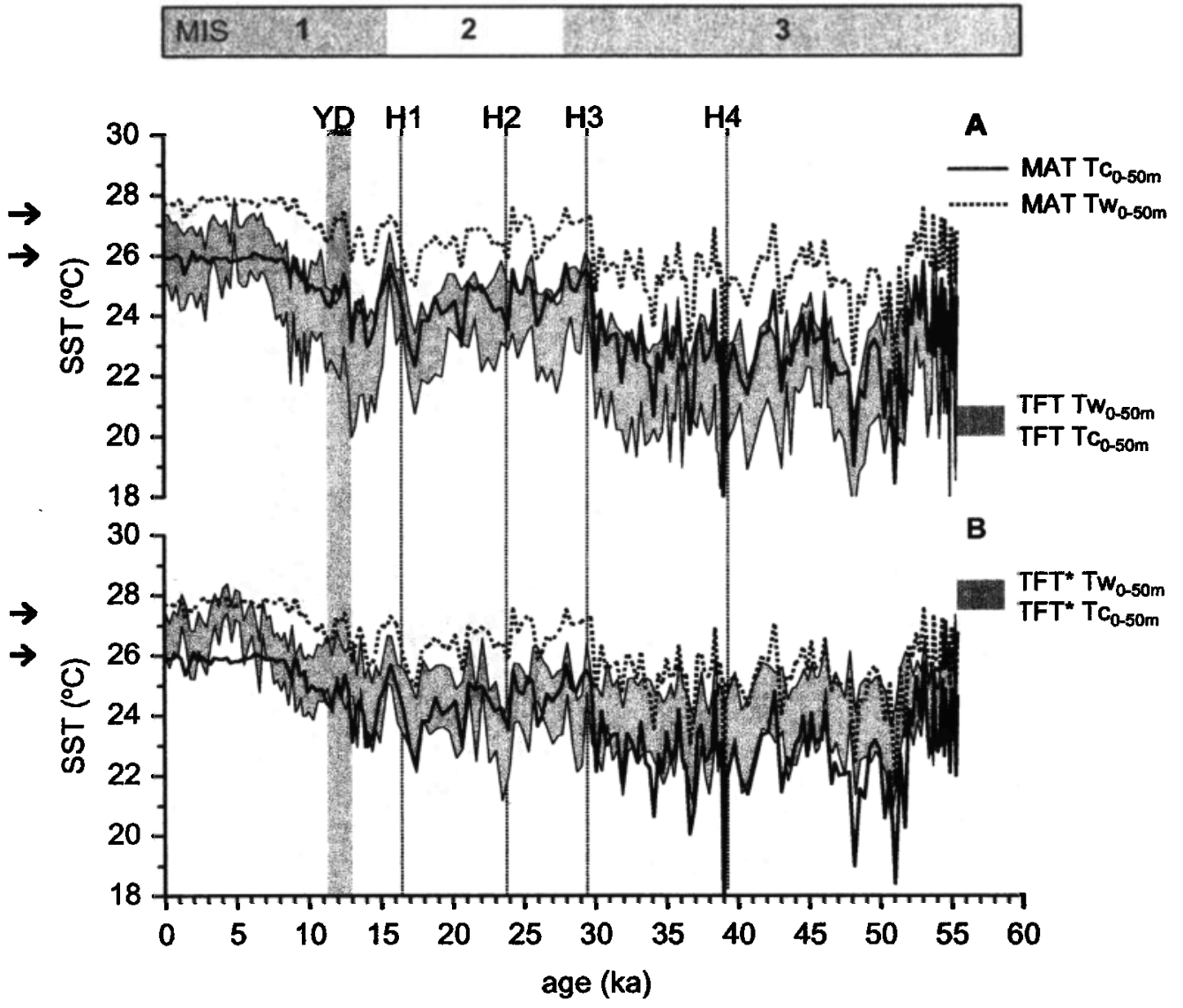

Figure 10. Comparison of SST estimates of M35003-4. (a) MAT (thick dashed line is $\mathrm{T}_{w}$, thick solid line is $\mathrm{T}_{c}$ ) versus TFT (gray shading between upper $\left(\mathrm{T}_{w}\right)$ and lower $\left(\mathrm{T}_{c}\right)$ thin lines); (b) MAT versus TFT*. Solid arrows mark modern seasonal SST level.

hanced carbonate accumulation at Venezuela Basin core sites [Bowles and Fleischer, 1985]. As enhanced upwelling would cause the thermocline to shoal, we would expect that a steeper surface-to-subsurface temperature gradient developed during the last glacial.

The vertical temperature gradient (Figure 12) that we derive for the upper $150 \mathrm{~m}$ indeed displays colder subsurface temperatures and a stronger vertical temperature gradient for the last glacial (Figure 12b). Together with glacially increased loadings of upwelling factor f8 estimates (Figure 12c) this points to enhanced upwelling and a shallower thermocline. Strongest cooling, steepest vertical temperature gradients, and highest productivity (as inferred from high accumulation of benthic foraminifera; see Figure 11e) are indicated for isotope stage 3. In particular for stage 3, upwelling factor f8 and SST display millennial-scale variability, linking enhanced upwelling at the core location with warm interstadial phases (Figure 12).

However, the pattern of SST, inferred upwelling, and paleoproductivity along core M35003-4 is not internally consistent throughout the records. For instance, paleoproductivity estimates, based on organic carbon accu- mulation rates along core M35003-4 (A. Vink et al., Glacial shifts in the position of the North Equatorial Current and the reflection of Heinrich events in the western subtropical Atlantic, submitted to Paleoceanography, 2000.) for stage 2, in part are lower than during the Holocene, even though inferred SST is colder and subsurface temperature gradients are steeper than during the Holocene. This indicates that temperature of the uppermost water column and inferred paleoproductivity and hence local upwelling intensity are not tightly linked. We thus consider the temperature records at large and the millennial-scale SST variability in particular to primarily document regional surface ocean variability in conjunction with larger-scale thermohaline forcing.

4.2.2. Thermohaline Forcing. Conceptual and numerical models indicate that reduced deep convection in the northern North Atlantic leads to reduced northward surface flow and warming of the South Atlantic and tropical Atlantic, largely due to a reduced marine heat export to the North Atlantic [Crowley, 1992; Stocker et al., 1992; Weaver and Hughes, 1994]. Core M35003-4 in the Tobago Basin is located along 


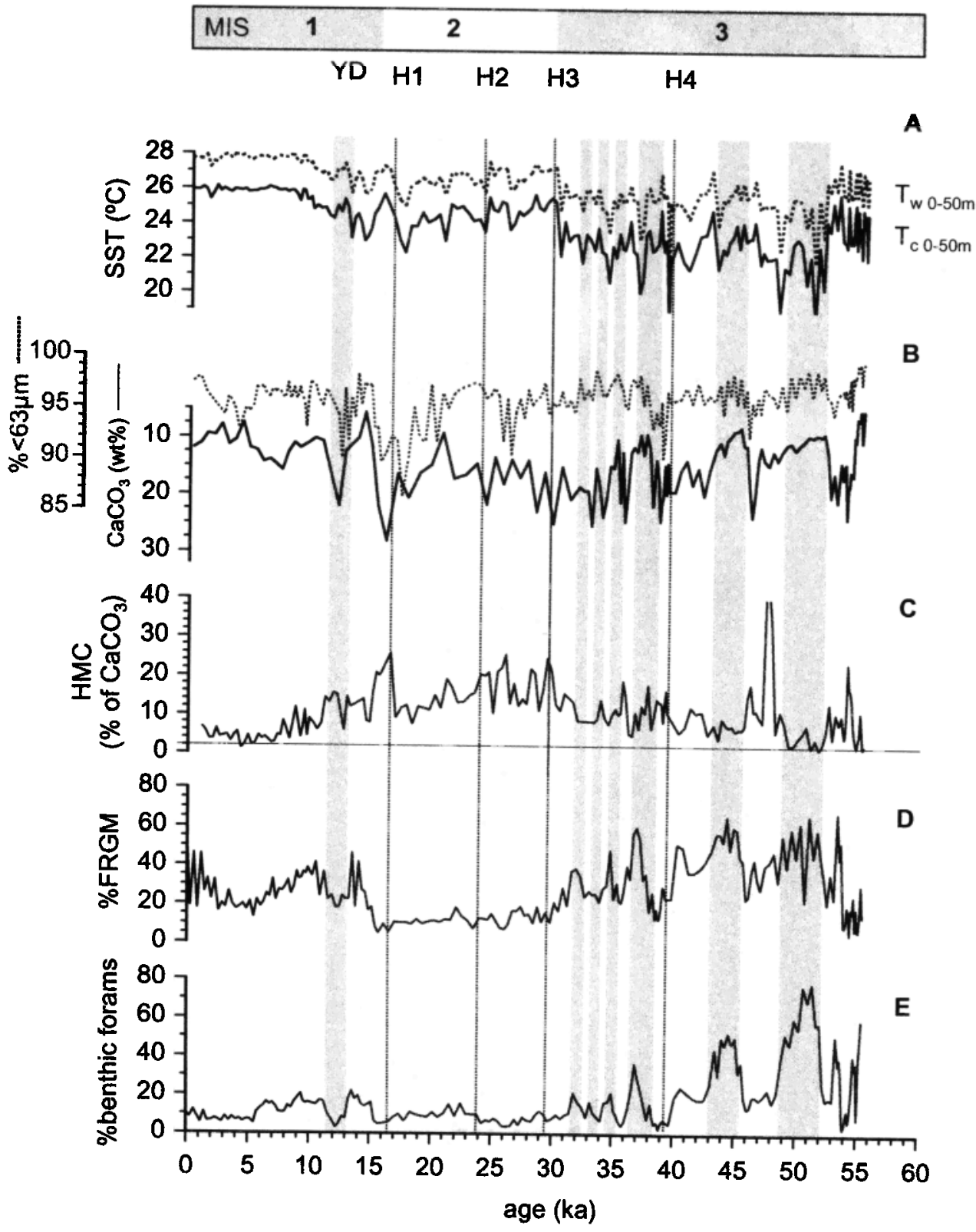

Figure 11. Comparison of carbonate dissolution and $\mathrm{SST}_{0-50 m}$ for M35003-4. (a) Cold and warm MAT SSTs; (b) carbonate (solid line) and $<63 \mu \mathrm{m}$ size fraction content (dashed line); (c) high-magnesium calcite (HMC) content in percent of carbonate fraction; (d) fragmentation of planktonic foraminifera; (e)
abundance of benthic foraminifera.

the northern extension of the cross-equatorial warm surface flow. The SST records from this core should thus record the behavior of the tropical North Atlantic warm pool during the rapid $\mathrm{D} / \mathrm{O}$ cycles recorded in the Greenland ice cores. To evaluate the surface ocean response from low to high northern Atlantic latitudes, we compare our SST record from the Tobago Basin to other records from sediment cores from the equatorial and midlatitude North Atlantic and to the GISP2 ice core record. The data we use are SST records from midlatitude cores SU90-03 $\left(40^{\circ} 03^{\prime} \mathrm{N}, 32^{\circ} 00^{\prime} \mathrm{W}\right.$ [Chapman and Shackleton, 1998]) and M15612 (44 ${ }^{\circ} 22^{\prime} \mathrm{N}, 26^{\circ} 33^{\prime} \mathrm{W}$ [Kiefer, 1998]) (Figure 13). We also use the nannofossil Florisphaera profunda abundance record of core RC24-08 from the eastern equatorial Atlantic $\left(01^{\circ} 20^{\prime} \mathrm{S}\right.$, $11^{\circ} 54^{\prime} \mathrm{W}$ [McIntyre and Molfino, 1996]). Total abundance of $F$. profunda is indicative of thermocline and mixed layer depths in that maximum abundances occur when the mixed layer is deep owing to reduced winddriven upwelling, while minimum abundances generally signify a shallow thermocline and intense upwelling [McIntyre and Molfino, 1996]). 


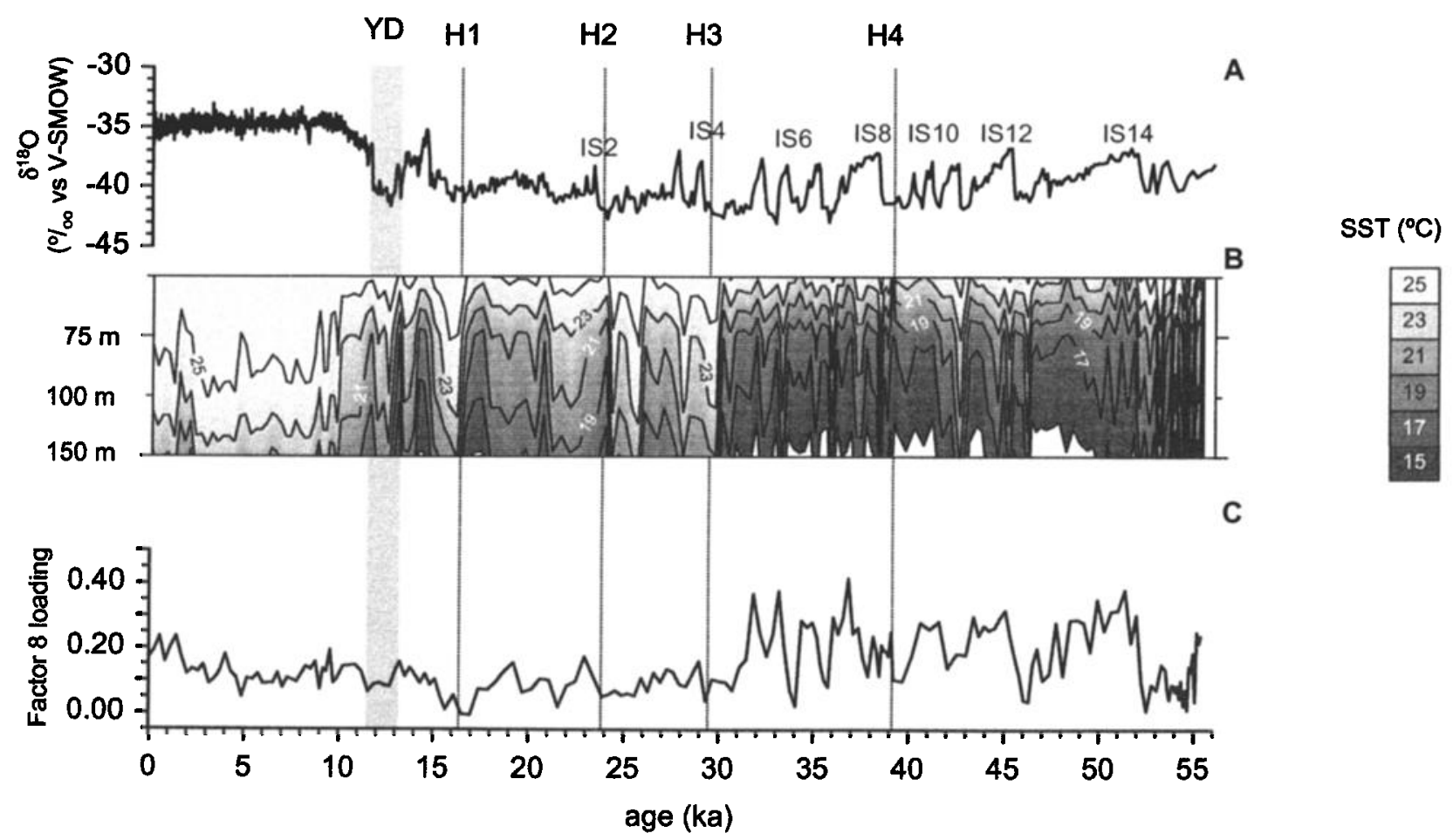

Figure 12. Temperature structure of the upper $150 \mathrm{~m}$ at the site of $\mathrm{M35003-4}$. (a) The $\delta{ }^{18} \mathrm{O}$ from GISP 2; (b) evolutionary SST and subsurface temperature for the upper $150 \mathrm{~m}$; (c) variation of South Atlantic upwelling assemblage (factor F8).

Precise correlation of the records obviously is an essential prerequisite for such correlation exercise. Detailed ${ }^{14} \mathrm{C}$ dating does not allow for tight correlation between different sediment cores because of uncertainties in converting ${ }^{14} \mathrm{C}$ ages to calendar years. Some of these problems can be circumvented using independent stratigraphic markers such as ice-rafted debris (IRD) layers or benthic $\delta^{13} \mathrm{C}$ or $\mathrm{Cd} / \mathrm{Ca}$ anomalies that can be linked to discrete climatic and oceanographic events, independent of their precise dating. In an attempt to constrain the correlation of the various records, we have used benthic Cd/Ca anomalies in core M35003-4 [Stüber, 1999; Zahn and Stüber, manuscript in preparation, 2000) and IRD layers in cores SU90-03 [Chapman and Shackleton, 1998] and M15612 [Kiefer, 1998] as markers for the Heinrich meltwater events and concomitant convection slowdown in the northern North Atlantic. Similar $\mathrm{Cd} / \mathrm{Ca}$ anomalies are observed and dated in cores from the midlatitude North Atlantic (Willamowski and Zahn, 2000 ), and ages of the IRD layers in core M15612 are well established [Kiefer, 1998]. We do not have similar markers from core RC24-08, so no independent stratigraphic tie points exist for this core. Thus the comparison of the different records remains circumstantial. We still present the comparison here as it is instructive in that it can be used to at least qualitatively test existing concepts that link high- and low-latitude cli- mates through changes in thermohaline circulation, and it makes the difficulties clear that are intrinsic to such comparison exercise.

Conceptual models [McIntyre and Molfino, 1996] postulate that SST in the Caribbean should increase during times of enhanced equatorial trade wind intensity owing to a stronger wind-driven advection of warm equatorial waters to the western subtropical North Atlantic. Enhanced trade wind intensity is indicated at the equator between 35 and $38 \mathrm{kyr}$ and $20-23 \mathrm{kyr}$ by abundance minima in $F$. profunda, which is indicative of increased upwelling. During both periods, SST and subsurface temperatures in core M35003-4 imply increased upwelling there, too.

Increased equatorial trade wind strength is also indicated by minimum abundance of $F$. profunda for Heinrich event 3. During this event, constrained by maximum $\mathrm{Cd} / \mathrm{Ca}$ ratios in benthic foraminifera [Stüber, 1999; Zahn and Stüber, manuscript in preparation, 2000], core M35003-4 in the Tobago Basin displays increased surface and subsurface temperatures, i.e., deepening of thermocline depths. SST at the midlatitude core sites are at a minimum (SU90-03) or remain low (M15612) (Figure 13). During H2, equatorial upwelling is low as implied by high abundances of $F$. profunda, indicating low trade wind intensities, and SST in core M35003-4 is at a minimum. Thus, where stratigraphic 


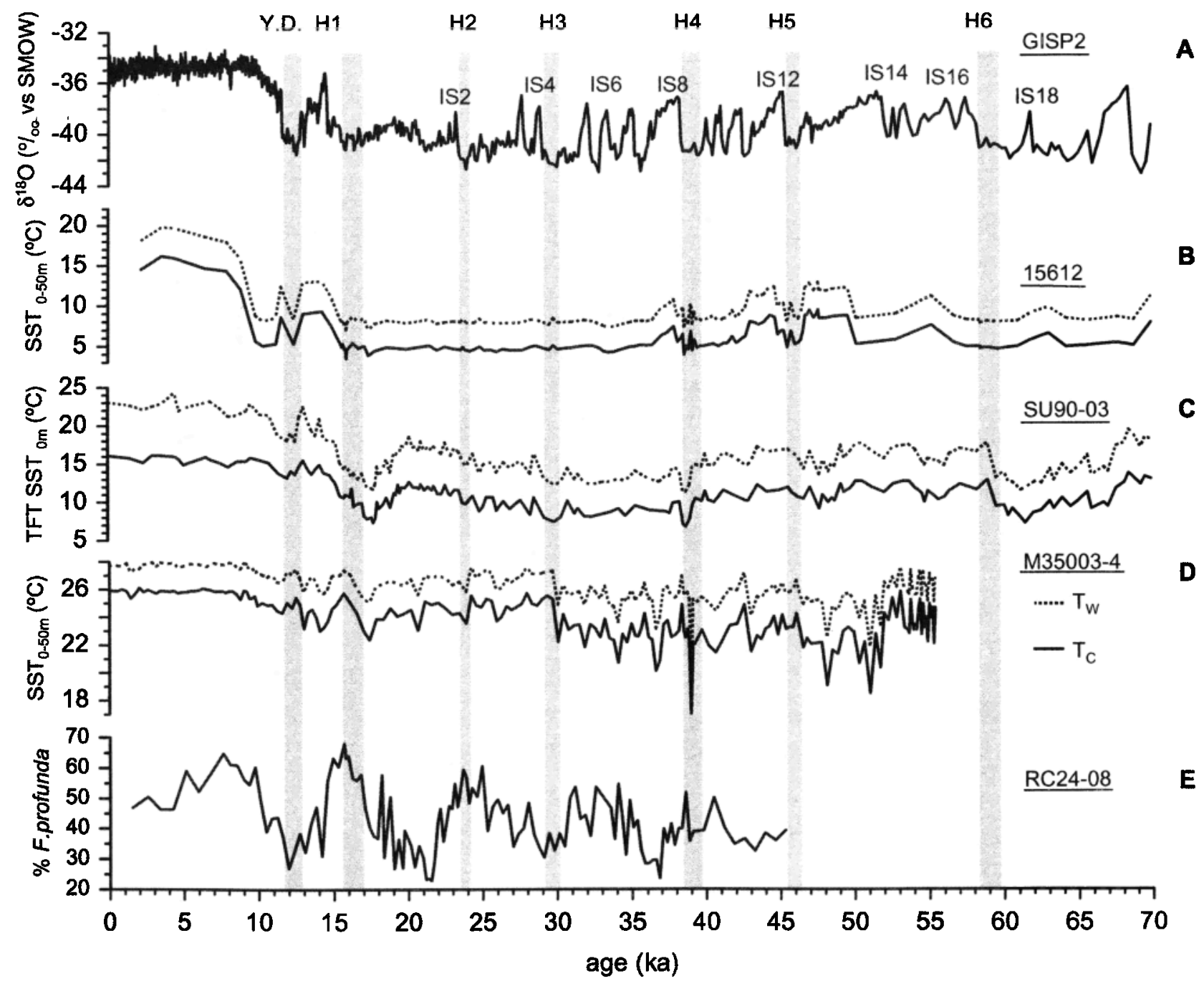

Figure 13. Comparison of late Pleistocene low-latitude to high-latitude Atlantic climate records. (a) GISP2 $\delta^{18} \mathrm{O}_{z c e}$ record [Grootes and Stuiver, 1997]; (b) SST $0-50 \mathrm{~m}$ from core M15612 $\left(44^{\circ} 22^{\prime} \mathrm{N}, 2^{\circ} 33^{\prime} \mathrm{W}\right.$; SST from MAT, using census counts of Kiefer [1998]); (c) $\mathrm{SST}_{0 m}$ from core SU90-03 $\left(40^{\circ} 03^{\prime} \mathrm{N}, 32^{\circ} 00^{\prime} \mathrm{W}\right.$; SST from transfer function FA20 for the Atlantic [Chapman and Shackleton, 1998]); (d) $\mathrm{SST}_{0-50 \mathrm{~m}}$ from core M35003-4 (this study); (e) Upwelling index from core RC24-08 (01 $20^{\circ} \mathrm{S}, 11^{\circ} 54^{\prime} \mathrm{W}$; percent of deepdwelling coccolithophoride $F$. profunda [McIntyre and Molfino, 1996]).

correlation is constrained by independent marker events (Cd/Ca maxima in core M35003-4), SST responses between the Tobago Basin and equatorial trade wind intensity fit conceptual models and confirm a link between atmospheric circulation and cross-equatorial marine heat transfer.

During Termination I the SST records at the lowlatitude and middle to high-latitude sites display an opposite trend. Stratigraphic correlation for this period is better constrained as the records contain significant variance associated with the Bølling-Allerød and Younger Dryas periods and, to some extent, with Heinrich event 1 (Figure 11). During Heinrich event 1, between 14.5 and 18 calendar kyr, when major cooling occurred throughout the northern North Atlantic region, core M35003-4 displays a warming of $\sim 2^{\circ}-3^{\circ} \mathrm{C}$. During the Bølling-Allerød period, when the North Atlantic region warmed, as seen in temperature records from cores SU90-03 and 15612, and in the GISP2 $\delta$ ${ }^{18} \mathrm{O}$ increase, core M35003-4 displays a subtle decrease in SST. During the Younger Dryas cold period, between 11 and 12.6 calendar kyr, equatorial core RC24-08 indicates enhanced upwelling, thus implying increased equatorial trade wind intensity. SST in Tobago Basin core M35003-4 during this period is warm, in agreement with the concept of enhanced cross-equatorial warm water flow during stronger trade winds [McIntyre and Molfino, 1996; Rühleman? et al., 1999] which would 
also be in line with warmer SST at western equatorial core sites [McIntyre et al., 1989] (Figure 13). The inference of enhanced trade wind strength is also in line with productivity records from the Cariaco Basin (foraminiferal fauna, stable isotopes of multiple planktonic foraminifera, and sediment laminae-thickness), which all point to enhanced wind-driven upwelling during the Younger Dryas [Peterson et al, 1991; Hughen et al.,1996, 1998; Lin et al., 1997]. Even though upwelling was enhanced, alkenone-derived SST estimates from ODP Site 1002 also display a warming during Younger Dryas (Herbert and Schuffert, 2000), and confirm the SST estimates from nearby Tobago Basin core M35003-4.

\section{Summary}

Sea surface temperature estimates along core M350034 from the western subtropical North Atlantic are used to reconstruct environmental variability in the area. Foraminiferal census counts reveal a high temporal variability of sea surface hydrography over the last 55 kyr. During glacial times, abundances of high-latitude planktonic foraminiferal assemblages are increased over those of tropical assemblages. Increased abundances of $N$. dutertrei, $N$. pachyderma (left and right coiling), and G. bulloides indicate a shoaling of thermocline depth, possibly in conjunction with a northward expansion of the Venezuelan upwelling area due to enhanced glacial trade wind intensity. SSTs estimated with the MAT and two different transfer-functions show a glacial-interglacial change of $2.5^{\circ}-3^{\circ} \mathrm{C}$. Largest SST decrease $\left(\Delta \mathrm{T}=4^{\circ} \mathrm{C}\right)$ is indicated for isotope stage 3 . Seasonal SSTs for the upper 0-50 m, annual temperature at 75,100 , and $150 \mathrm{~m}$ water depth indicate steeper vertical temperature gradients during the last glacial and thus a shallow thermocline $(75 \mathrm{~m}$ versus $150 \mathrm{~m}$ during the Holocene). Absolute SST estimates are different for the different techniques applied (MAT after Prell [1985]; TFT after Imbrie and Kipp [1971]; TFT* after Mix et al. [1999]), but the records all show the same trend and pattern. Millennial-scale variability during stage 3 and during Termination $I$ is indicated, similar to that seen in the Greenland ice core record. Temperature shifts at our Tobago Basin core during these episodes are partially opposite to those observed at high-latitude core sites. That is, SST estimates for core M35003-4 show short warmings during Heinrich events $\mathrm{H} 1$ and $\mathrm{H} 3$ and during the Younger Dryas period when northern North Atlantic climatic records imply major cooling. General circulation model studies [Manabe and Stouffer, 1988; Rahmstorf, 1994) postulate inverse temperature patterns between the low- and high-latitude North Atlantic as a function of varying strength of thermohaline circulation and northward marine heat transport.

Comparison of SST records from the equatorial and subtropical Atlantic, the Caribbean, and the North Atlantic thus is indicative of some connection between the intensity of ocean thermohaline circulation, atmospheric circulation, and SST evolution in the tropical to high-latitude North Atlantic. This is best displayed during Termination I and the Heinrich events when larger-amplitude climatic excursions occur. During the earlier parts of the records, in particular during isotope stage 3 when $\mathrm{D} / \mathrm{O}$ cycles are best developed, a precise correlation of SST signals from low- to middle and high-latitude records is hampered by the difficulty of detailed stratigraphic control. This calls on better stratigraphic correlation methods by way of independent marker events, such as benthic $\delta^{13} \mathrm{C}$ and $\mathrm{Cd} / \mathrm{Ca}$ anomalies, which are linked to discrete paleoceanographic events which occur synchronously and basin wide. Paleomagnetic intensity excursions (Mono Lake, Lachamp) provide further stratigraphic tielines and will enable fine-scale stratigraphic cross correlation between core sites.

Acknowledgments. We thank A. Stüber, J. Schönfeld, C. Rühlemann, S. Mulitza, and A. Müller for stimulating discussions. M. Chapmann and one anonymous reviewer provided constructive comments on the manuscript. We are indebted to U. Pflaumann for providing access to his foraminiferal reference database and introducing M.H. into the Fortran algorithms for SST estimation. Radiocarbon analyses were carried out at the Leibniz Laboratory for Isotope Research, Kiel University, under the supervision of P. Grootes and M.-J. Nadeau. Carbonate records were measured by L. Lembke. We thank M. Kull, Captain of R/V Meteor, and his crew of cruise M35/1 who helped obtaining the core used in this study. Special thanks go to C. Hemleben for arranging the Tobago Basin part of the cruise. This work was funded by the Deutsche Forschungsgemeinschaft through grant Za157/13 to R.Z.

\section{References}

Andreason, D.J., and A.C. Ravelo, Tropical Pacific Ocean thermocline depth reconstructions for the last glacial maximum., Paleoceanography, 12, 395-413, 1997.

Behl, R. J., and J.P. Kennett, Brief interstadial events in the Santa Barbara basin, NE Pacific, during the past 60 kyr, Nature, 379, 243-246, 1996.

Berger, W., Plankton foraminifera: Selec- tive solution and paleoclimatic interpretation, Deep Sea Res., 15, 31-43, 1968.

Berger, W.H., Planktonic foraminifera: Selective solution and the lysocline, Mar. Geol., 8, 111-138, 1970.

Blunier, T., et al., Asynchrony of Antarctic and Greenland climate change during the last glacial period, Nature, 394, 739-743, 1998.

Bond, G. ,W.C. Broecker, S. Johnsen, J.
McManus, L. Labeyrie, J. Jouzel, and G. Bonani, Correlations between climate records from North Atlantic sediments and Greenland ice, Nature, 365, 143147, 1993.

Bond, G.C., and R. Lotti, Iceberg discharges into the North Atlantic on millennial time scales during last glaciation, Science , 267, 1005-1010, 1995.

Bowles, F.A., and P. Fleischer, Orinoco 
and Amazon River sediment input into the eastern Caribbean Basin, Geology, $68,53-72,1985$.

Boyle, E.A., and L. Keigwin, North Atlantic thermohaline circulation during the past 20,000 years linked to highlatitude surface temperatures, Nature, 330, 35-40, 1987.

Chapman, M. R., and N.J. Shackleton, Millennıal - scale fluctuations in North Atlantic heat flux during the last 150,000 years, Earth Planet. Scr. Lett., 159, $57-70,1998$.

Charles, C. D., J. Lynch-Stieglitz, U.S. Ninnemann, and R.G. Fairbanks, Climate connections between the hemisphere revealed by deep sea sediment core / ice core correlations, Earth Planet. Sci. Lett., 142, 19-27, 1996.

Crowley, T.J., North Atlantic Deep Water cools the Southern Hemisphere, Paleoceanography, 7, 489-497, 1992.

Curry,W.B., and D. Oppo, Synchronous, high-frequency oscillations in tropical sea surface temperatures and North Atlantic Deep Water production during the last glacial cycle, Paleoceanography, 12, 114, 1997.

Dansgaard, W., et al., Evidenco: for general instability of past climate from a 250 kyr ice-core record, Nature, 339, 532$534,1993$.

Davis, J.C., Statıstrcs and Data Analysis in Geology, 646 pp., John Wiley, New York, 1986.

Dawsett, H.J., and R.Z. Poore, A new planktic foraminifer transfer function for estimating Pliocene-Holocene paleoceanographic conditions in the North Atlantic, Mar. Micropaleontol., 16, 1-26, 1990.

DeMiro, M.D., Los foraminiferos vivos y sedimentados del margen continental de Venezuela (resumen), Acta Geol. Hrsp., $6(4), 102-106,1971$.

Duplessy, J.-C., N.J. Shackleton, R.K. Mathews, W. Prell, W.F. Ruddiman, M. Caralp, and C.H. Hendy, ${ }^{13} \mathrm{C}$ record of benthic foraminifera in the last interglacial ocean: Implications for the carbon cycle and the global deep water circulation, Quaternary Research, 21, 225-243, 1984.

Fairbanks, R.G., M. Sverdlove, R. Free, P.H. Wiebe, and A. B, Vertical distribution and isotopic fractionation of living planktonic foraminifera from the Panama Basin, Nature, 298, 841-844, 1982.

Giradeau, J., and J. Roger, Phytoplankton biomass and sea-surface temperature estimates from sea-bed distribution of nannofossils and plankton foraminifera in the Benguela upwelling system, $\mathrm{Mz}$ cropaleontology, 40, 275-285, 1994.

Gonzalez-Donozo, J.M., and D. Linares, Evaluation of some numerical techniques for determining paleotemperatures from planktonic foraminiferal assemblages, $R e$ vista Espanola Paleontol., 13(1), 107129, 1998.

Grootes, P. M., and M. Stuiver, Oxygen
$18 / 16$ variability in Greenland snow and ice with $10^{-3}$ to $10^{-5}$-year time resolution, J. Geophys. Res., 102, 26,45526,470, 1997.

Grootes, P.M., M. Stuiver, J.W.C. White, S. Johnsen, and J. Jouzel, Comparison of the oxygen isotope records from the GISP2 and GRIP Greenland ice cores, Nature, 366, 552-554, 1993.

Haug, G. H., T.F. Pederson, D.M. Sigman, S.E. Calvert, B. Nielsen, and L.C. Peterson, Glacial/interglacial variations in the production and nitrogen fixation in the Cariaco Basin during the last 580 kyr, Paleoceonography, 13, 427-432, 1998.

Hemleben, C., M. Spindler, and O.R. Anderson, Modern Planktonic Foraminifera, 335 pp., Springer-Verlag, New York, 1989. Herbert, T.D., and J.D. Schuffert, Alkenone unsaturation estimates of sea-surface temperatures at ODP Site 1002 over a full glacial cycle, in Proc. Ocean Drall. Program, Sci. Results, edited by R.M. Leckie et al., pp. 239-247, 2000.

Herguera, J.C., and W.H. Berger, Paleoproductivity from benthic ioraminiferal abundance: Glacial to postglacial change in the west-equatorial Pacific, Geology, 19, 1173-1176, 1991.

Hostetler, S.W., and A.C. Mix, Reassessment of ice-age cooling of the tropical ocean and atmosphere, Nature, 399,673$676,1999$.

Hughen, K. A., J.T. Overpeck, S.J. Lehman, M. Kashgarian, J. Southon, L.C. Peterson, R. Alley, and D.M. Sigman, Rapid climate changes in the tropical Atlantic region during the last deglaciation, $\mathrm{Na}$ ture, 380, 51-54, 1996.

Hughen, K. A., J.T. Overpeck, S. Lehman, M. Kashgarian, J. Southon, L.C. Peterson, R. Alley, and D.M. Sigman, Deglacial changes in ocean circulation from extended radiocarbon calibration, $\mathrm{Na}$ ture, 391, 65-68, 1998.

Hutson, W.H., Transfer functions under no-analog conditions: Experiments with Indian Ocean planktonic foraminifera, Quat. Res., 8, 355-367, 1977.

Imbrie, J., and N.G. Kipp, A new micropaleontological method for quantitative paleoclimatology: Application to a late Pleistocene Caribbean core, in The Late Cenozorc Glacial Ages, edited by K.K. Turekian, pp. 71-181, Yale Univ. Press, New Haven, Conn., 1971.

Imbrie, J., et al., Specmap Archive No.1, IGBP PAGES World Data Center-A for Paleoclımatol. Data Contrib. Ser. 90001, NOAA/NGDC Paleoclimatol. Program, Boulder, Colo., 1990.

Ivanova, E. M., S.M.-H. Conan, F.J.C. Peeters, and S.R. Troelstra, Living Neogloboquadrina pachyderma sin and its distribution in the sediments from Oman and Somalia upwelling areas, Micropaleontology, 36, 91-107 1999.

Jung, S.J.A., Wassermassenaustausch zwischen NE-Atlantik und Nordmeer wäh- rend der letzten 300 000/80 000 Jahre im Abbild stabiler O- und C-Isotope, Ber. Sonderforschungsber. 313 (61), 104 pp., 1996.

Keigwin, L.D., and E.A. Boyle, Sprface and deep ocean variability in the northern Sargasso Sea during marine isotope' stage 3, Paleoceanography, 14, 164-170, 1999.

Keigwin, L.D., and G.A. Jones, Western North Atlantic evidence for millennialscale changes in ocean circulation and climate, J. Geophys. Res., 99, 12.39712.410, 1994.

Kennett, J.P., and L. Ingram, A 20,000 year record of ocean circulation and climate change from the Santa Barbara Basin, Nature, 377, 510-514, 1995.

Kennett, J.P., and M.S. Srinivasan, Neogene planktonic foraminifera: A phylogenetic atlas., 263 pp., Van Nostrand Reinhold, New York, 1983.

Kiefer, T., Produktivität und Temperaturen im subtropischen Nordatlantik: Zyklische und abrupte Veränderungen im späten Quartär (Productivity and temperatures in the subtropical North Atlantic: cyclic and abrupt changes during the Late Quaternary), Ber. Geol. Palä.ontol. Inst. 90, 127 pp., University of Kiel, Germany, 1998.

Kinder, T.H., G.W. Heburn, and A.W. Green, Some aspects of the Caribbean circulation, Geology, 68, 25-52, 1985.

Kipp, N., New transfer function for estimating past sea surface conditions from sea bed distribution of planktonic foraminiferal assemblages in the North Atlantic, in Investrgation of Late Quaternary Paleoceanography and Paleoclimatology, edited by R. M. Cline and J. D. Hays, Mem. Geol. Soc. Am., 145, 3-41, 1976.

Klovan, J.E., and J. Imbrie, An algorithm and Fortran IV program for large-scale Q-mode factor analysis and calculation of factor scores, Geology, 3, 61-77, 1971.

Laj, C., A. Mazaud, and J.C. Duplessy, Geomagnetic intensity and ${ }^{14} \mathrm{C}$ abundance in the atmosphere and ocean during the past $50 \mathrm{kyr}$, Geophys. Res. Lett., 23,2046-2048, 1996.

Le, J., and R.C. Thunell, Modelling planktic foraminiferal assemblages changes and application to sea surface temperatures estimation in the western equatorial $\mathrm{Pa}$ cific Ocean, Mar. Micropaleontol., 28, 211-229, 1996.

Lebreiro, S.M., J.C. Moreno, I.N. McCave, and P.P.E. Weaver, Evidence for "Heinrich" layers off Portugal (Torre Seamount: $\left.39^{\circ} \mathrm{N}, 12^{\circ} \mathrm{W}\right)$, Mar. Geol., 131, 47-56, 1996.

Levitus, S., and T.P. Boyer, World Ocean Atlas 1994 Volume 4: Temperature, NOAA Atlas NESDIS 4, U.S. Department of Commerce, Washington, D.C., 1994.

Lin, H.-L., L.C. Peterson, J.T. Overpeck, S.E. Trumbore, and D.W. Murray, Late Quaternary climate change from $\delta^{18} \mathrm{O}$ 
records of multiple species of planktonic foraminifera: High- resolution records from the anoxic Cariaco Basin, Venezuela, Paleoceanography, 12, 415-427, 1997.

Little, M.G., R.R. Schneider, D. Kroon, B. Price, C.P. Summerhayes, and M. Segl, Trade wind forcing of upwelling, seasonality, and Heinrich events as a response to sub- Milankovitch climate variability, Paleoceanography, 12, 568-576, 1997.

Lund, D.C., and A.C. Mix, Millenial-scale deep water oscillations: Reflections of the North Atlantic in deep Pacific from 10 to $60 \mathrm{ka}$, Paleoceanography, 13, 10$19,1998$.

Manabe, S., and R.J. Stouffer, Two stable equilibria of a coupled ocean - atmosphere model, J. Clim., 1, 841-868, 1988.

Manabe, S., and R.J. Stouffer, Coupled ocean - atmosphere model response to freshwater input: Comparison to Younger Dryas event, Paleoceanography, 12, 321336, 1997.

Marchitto, T.M., W.B. Curry, and D.W. Oppo, Millenial-scale changes in North Atlantic circulation since the last glaciation, Nature, 393, 557-561, 1998.

Martinez, P., P. Bertrand, G.B. Shimmield, K. Cochrane, F.J. Jorissen, J. Foster, and M. Dignan, Upwelling intensity and ocean productivity changes off Cape Blanc (northwest Africa) during the last 70,000 years: Geochemical and micropaleontological evidence, Geology, 158, 57-74, 1999.

Martinson , D.G., N.G. Pisias, J.D Hays, J. Imbrie, T.C. Moore, and N.J. Shackleton, Age dating and the orbital theory of the Ice Ages: Development of a highresolution 0 to 300,000 -year chronostratigraphy, Quat. Res., 27, 1-29, 1987.

Maslin, M.A., N.J. Shackleton, and U. Pflaumann, Surface water temperature, salinity and density changes in the NE- Atlantic during the last 45,000 years: Heinrich events, deep water formation and climate rebounds, Paleoceanography, 10, 527-544, 1995.

Mayewski, P.A., et al., Changes in atmospheric circulation and ocean ice cover over the North Atlantic during the last 41,000 years, Science, 263, 1747-1751,

McIntyre, A., and B. Molfino, Forcing of Atlantic equatorial and subpolar millenial cycles by precession, Science, 274, 1867-1870, 1996.

McIntyre, A., W.F. Ruddiman, K. Karlin, and A.C. Mix, Surface water response of the equatorial Atlantic Ocean to orbital forcing, Paleoceonography, 4, 19$55,1989$.

Mix,A.C., and A.E. Morey, Climate feedback and Pleistocene variations in the Atlantic south equatorial current, in The South Atlantrc, Present and Past Circulation, edited by G.Wefer et al., pp. 503525, Springer-Verlag, New York, 1996.

Mix, A.C., W.F. Ruddiman, and A. McIn- tyre, Quaternary paleoceanography of the tropical Atlantic, 1, Spatial variability of annual mean sea-surface temperatures, 0-20,000 years B.P., Paleoceanography, 1, 43-66, 1986a.

Mix, A. C., W.F. Ruddiman, and A. McIntyre, Late Quaternary paleoceanography of the tropical Atlantic, 2, The seasonal cycle of sea surface temperatures, $0-20,000$ years B.P., Paleoceanography, 1, 339$353,1986 \mathrm{~b}$.

Mix, A. C., A.E. Morey, N.G. Pisias, and S.W. Hostetler, Foraminiferal faunal estimates of paleotemperature: Circumventing the no-analog proplem yields cool 1ce age tropics, Paleoceanography, 14, 350-359, 1999

Molfino, B., N.G. Kipp, and J.J. Morley, Comparison of foraminiferal, coccolithophorid and radiolarian paleotemperature equations: Assemblage coherency and estimate concordancy, Quat. Res., 17, 279-313, 1982.

Müller-Karger, F. E., and A. Castrot, Mesoscale processes affecting phytoplankton abundance in the southern Caribbean Sea, Cont. Shelf Res., 14(2/3), 99-221, 1994.

Nadeau, M.-J., M. Schleicher, P.M. Grootes H. Erlenkeuser, A. Gottdang, D.J.W. Mous, M. Sarnthein, and H. Willkomm, The Leibniz-Laboratory AMS facility at the Christian-Albrechts University, Kiel, Germany, Instrum. Methods Phys. Res., Ser. B, 123, 22-30, 1997.

Oppo, D. W., M.E. Raymo, G.P. Lohman, A.C. Mix, J.D. Wright, and W.L. Prell, A $\delta{ }^{13} \mathrm{C}$ record of Upper North Atlantic Deep Water during the past 2.6 million years, Paleoceanography, 10, 373394, 1995.

Overpeck, J.T., T. Webb, and I.C. Prentice, Quantitative interpretation of fossil pollen spectra: Dissimilarity coefficients and the method of modern analogs, Quat. Res., 23, 87-108, 1985

Peterson, L.C., J.T. Overpeck, N.G. Kipp, and J. Imbrie, A high-resolution late Quaternary upwelling record from the anoxic Cariaco Basin, Venezuela, Paleoceanography, 6, 99-119, 1991.

Peterson, R.G., and L. Stramma, Upperlevel circulation in the South Atlantic Ocean, Progr. Oceanogr., 26, 1-73, 1991.

Pflauman, U., J. Duprat, C. Pujol, and L.D. Labeyrie, SIMMAX: A modern analog technique to deduce Atlantic sea surface temperatures from planktonic foraminifera in deep-sea sediments, Paleoceanography, 11, 15-35, 1996.

Prell, W.L., The stability of low latitude sea surface temperatures: An evaluation of the CLIMAP reconstruction with emphasis on positive SST anomalies, Rep. TR 025, 60 pp., U.S. Dep. of Energy, Washington, D.C., 1985.

Rahmstorf, S., Rapid climate transitions in a coupled ocean-atmosphere model, Nature, 372, 82-85, 1994.

Rasmussen, T. L., E. Thomsen, T.C.E. van Weering, T.C.E., and L. Labeyrie, Rapid changes in surface and deep water conditions at the Faeroe Margin during the last 58,000 years, Paleoceanography, $11,757-771,1996$.

Ravelo, A.C., and D.H. Andreason, Using planktonic foraminifera as monitors of tropical surface ocean, in Reconstructang Ocean History: $A$ Window into the Future, edited by F. Abrantes and A. Mix, pp. 217-243, Kluwer Acad., New York, 1999.

Ravelo, A.C., R.G. Fairbanks, and S.G.H. Philander, Reconstructing tropical A1, lantic hydrography using planktonic foraminifera and an ocean model, Paleoceanography, 5, 409-431, 1990.

Ruddiman, W. F., Tropical Atlantic terrigeneous fluxes since 25,000 yrs BP, Geology, 136, 189-207, 1997.

Rühlemann, C., S. Mulitza, P.J. Müller, G. Wefer, and R. Zahn, Tropical Atlantic warming during conveyor shutdown: Nature, 402, 511-514, 1999.

Sarnthein, M., K. Winn, S..J.A. Jung, J.C. Duplessy, L. Labeyrie, H. Erlenkeuser and G. Ganssen, Changes in east Atlantic deepwater circulation over the last 30,000 years: Eight time slice reconstructions, Paleoceanography, 9, 209-267, 1994

Sarnthein, M., et al., Variations in Atlantic surface ocean paleoceanography, $50^{\circ}-80^{\circ} \mathrm{N}$ : A timeslice record of the last 30,000 years, Paleoceanography, 10, 10631094, 1995.

Sautter, L.A., and R.C. Thunell, Seasonal variability in the $\delta^{18} \mathrm{O}$ and $\delta^{13} \mathrm{C}$ of planktonic foraminifera from an upwelling environment: Sediment trap results from the San Pedro Basin, Southern California Bight, Paleoceanography, 6, 307-334, 1991.

Schleicher, M., P.M. Grootes, M.-J. Nadeau, and $\mathrm{A}$. Schoon, The carbonate ${ }^{14} \mathrm{C}$ background and its components at the Leibniz AMS facility, Radiocarbon, 40, 8593, 1998.

Schott, F., and R.L. Molinari, The western boundary circulation of the subtropical warmwatersphere, in The Warmwatersphere of the North Atlantic Ocean, edited by W. Krauss, pp. 229-252, Gebrüder Borntraeger, Stuttgart, Germany, 1996.

Schulz, H., U. von Rad, and H. Erlenkeuser, Correlation between Arabian Sea and Greenland climate oscillations of the past 110,000 years, Nature, 393, 54-57, 1998.

Stocker, T. F., D.G. Wright, and L.A. Mysak, A zonally averaged, coupled ocean - atmosphere model for paleoclimate studies, J. Climatol., 5, 773-797, 1992.

Stramma, L., Geostrophic transport of the South Equatorial Current in the Atlantic, J. Mar. Res., 49, 281-294, 1991.

Stramma, L., and F. Schott, Western equatorial circulation and interhemispheric exchange, in The Warmwatersphere of the North Atlantic Ocean, edited by W. 
Krauss, pp. 195-227, Gebrüder Borntraeger, Stuttgart, Germany, 1996.

Stüber, A., Spätpleistozäne Variabilität der Zwischenwasserzirkulation im subtropischen Westatlantik auf glazial - interglazialen und suborbitalen Zeitskalen: Rekonstruktion anhand stabiler Kohlenstoffisotope und Spurenmetallverhältnissen in kalkschaligen Benthosforaminiferen, Ph.D. thesis, Christian Albrechts Univ., Kiel, Germany, 1999.

Stuiver, M., and P.J. Reimer, Extended ${ }^{14} \mathrm{C}$ database and revised CALIB radiocarbon calibration program, Radiocarbon, 35, 215-230, 1993.

Stuiver, M., P.J. Reimer, E. Bard, J.W. Beck, G.S. Burr, K.A. Hughen, B. Kromer, F.G. McCormac, J. van der Plicht, and M. Spurk, INTCAL98 radiocarbon age calibration 24,000 - 0 cal BP, Radiocarbon, 40, 1041-1083, 1998.

Taylor, K. C., C.U. Hammer, R.B. Alley, H.B. Clausen, D. Dahl-Jensen, A.J. Gow, N.S. Gundestrup, J. Kipfstuhl, J.C. Moore, and E.D. Waddington, Electrical conductivity measurements from GISP2 and GRIP Greenland ice cores, Nature, 366, 549-552, 1993.

Ufkes, E., and W.J. Zachariasse, Origin of coiling differences in living neogloboqua- drinids in the Walvis Bay region, off Namibia, southwest Africa, Micropaleontology, 39, 283-287, 1993.

Ufkes, E., J.H. Jansen, and G.-J.A. Brummer, Living planktonic foraminifera in the eastern South Atlantic during spring: Indicators of water masses, upwelling and the Congo (Zaire) River plume, Mar. Micropaleontol., 33, 27-53, 1998.

Völker, A.H.L., M. Sarnthein, P.M. Grootes, H. Erlenkeuser, C. Laj, A. Mazaud, M.-J. Nadeau, and M. Schleicher, Correlation of marine ${ }^{14} \mathrm{C}$ ages from the Nordic Seas with GISP2 isotope record: Implications for radiocarbon calibration beyond 25 ka B.P., Radiocarbon, 40, 517534, 1998.

Waelbroeck, C., L. Labeyrie, J.-C. Duplessy, J. Guiot, M. Labracherie, H. Leclaire, and J. Duprat, Improving past sea surface temperature estimates based on planktonic fossil faunas, Paleoceanography, 13, 272-283, 1998.

Wang, L., M. Sarnthein, J.-C. Duplessy, H. Erlenkeuser, S.J.A. Jung, and U. Pflaumann, Paleo sea surface salinities in the low-latitude Atlantic: The $\delta^{18} \mathrm{O}$ record of Globıgerznoides ruber (white), Paleoceanography, 10, 749-761, 1995.

Weaver, A.J., and T.M.C. Hughes, Rapid interglacial climate fluctuations driven by North Atlantic Ocean circulation, $\mathrm{Na}$ ture, 367, 447-450, 1994.

Willamowski, C., and R. Zahn, Upper ocean circulation in the glacial North Atlantic from benthic foraminiferal isotope and trace element fingerprinting, Paleoceonography, in press, 2000.

Zahn, R., J. Schönfeld, H.-R. Kudrass, M.-H. Park, H. Erlenkeuser, H., and P. Grootes, Thermohaline instability in the North Atlantic during meltwater events: Stable isotope and ice-rafted detritus records from core So75-26KL, Portuguese margin, Paleoceanography, 12, 696-710, 1997.

M. Hüls, GEOMAR Research Center for Marine Geosciences, Wischhofstrasse 1-3, D-24148 Kiel, Germany. e-mail: mhuels@geomar.de

R. Zahn, Cardiff University, Park Place, Cardiff, CF10 3YE, Wales, UK. e-mail: ZAHNR@cf.ac.uk

(Received September 28, 1999; revised July 31, 2000;

accepted August 14, 2000.) 